Boise State University

ScholarWorks

Communication Faculty Publications and

Presentations

Department of Communication

$1-10-2013$

\title{
The Closing of the Ether: Communication Policy and the Public Interest in the United States and Great Britain, 1921-1926
}

Seth Ashley

Boise State University 


\section{THE ClOSING OF THE ETHER: COMMUNICATION POLICY AND THE PUbliC INTEREST IN THE UNITED STATES AND GREAT BRITAIN, 1921-1926}

\section{SETH ASHLEY}

How do media systems come to be structured in different ways? Through a comparative historical institutional analysis of the origins of broadcasting policy in the United States and Great Britain in the early twentieth century, this study examines reasons that private, commercial interests dominated the U.S. system while Britain granted a monopoly to the publicly funded, noncommercial BBC. Policy outcomes at this critical juncture were contingent on different pathdependent notions of the public interest as well as temporal sequencing. Through an analysis of primary documents and secondary literature, this study considers the implications of these different approaches for modern communication policy and democratic society.

Critical discussions of the structure and function of media systems often center on the notion that there is nothing inherently natural about the way media

\footnotetext{
* Assistant Professor, Department of Communication, Boise State University
} 
systems develop over time. ${ }^{1}$ Rather, media systems evolve due to deliberate and accidental policies and practices that exist within social and political contexts. Once certain paths are selected, policy outcomes can have lasting effects. But how does this process unfold, and what factors lead to different outcomes?

Following previous research that has identified the origins of broadcast media as a major critical juncture in the history of communication, ${ }^{2}$ this study presents a comparative historical institutional analysis of the origins of broadcasting policy in the United States and Great Britain in the early twentieth century. Although the countries are fundamentally similar, they took notably different approaches to structuring and regulating broadcast media. In the United States, private, commercial media were fully institutionalized in the 1930s, while in Britain, the noncommercial, publicly funded BBC held a monopoly. How could two similar nations, sharing the same ostensible concern

1 See Jurgen Habermas, The Structural Transformation of the Public SpHere (1989);

Daniel C. Hallin \& PaOlo Mancini, Comparing Media Systems: Three Models of Media AND Politics 2 (2004); Robert W. McChesney, THe Problem OF THE Media: U.S. COMMUNiCATION Politics in the 21st Century 18 (2004); PAUl Stark, The Creation of the Media: Political ORIGINS OF MODERN COMMUNICATIONS 1-2 (2004).

2 See Robert W. McCheSney, TelecommunicAtion, MASs Media AND Democracy: The BATTLE FOR THE CONTROL OF U.S. BROADCASTING, 1928-1935 (1993); SUSAN SMULYAN, SELLING RAdio: The CommercializATION OF AMERICAN BROAdCASTING, 1920-1934 (1994); THOMAS

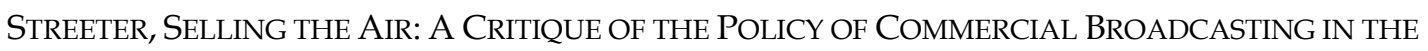
UNITED STATES (1996). 
for the public interest, produce such drastically different outcomes? How did different conceptions of the public interest shape these early broadcasting policy outcomes? Through an analysis of primary sources and secondary literature, this study examines the origins of broadcast policy in the 1920s, from the emergence of broadcasting as a popular medium in 1921 up to the institutionalization of modern policy structures in 1927, in an attempt to better understand how today's media landscape came to be and to consider how media systems can be best equipped to enhance democratic practices.

The goals of the study are to synthesize existing literature, uncover additional primary source detail to supplement the rich body of work that already exists, and make a useful case comparison that helps illustrate and explain divergent policy outcomes. This historical analysis will show that although both systems represent a top-down process of closing the ether to new entrants as power was concentrated, the outcomes exemplified and hinged on two radically different conceptions of the role of the state in regulating media. Where the American design was dominated by capitalist concerns for profit and growth, the British outcome was better able to preserve democratic impulses. The public-interest concept that guided the American outcome was embedded in a market orientation and gave preference to industry and economic concerns, while the British outcome was motivated by paternalistic notions of public service, which treated broadcasting more like a utility designed to bring quality content to citizens. Notably, both countries avoided the more extreme options: a 
free-market property rights solution on one hand and a total government takeover on the other. Both systems have seen changes since their origins, but these early designs still resonate strongly today.

\section{THEORETICAL FRAMEWORK}

All the modern social sciences - and especially sociology - were originally a response to the effects of the industrialization and commercialization of society in the nineteenth century. ${ }^{3}$ Through a range of methods, scholars have attempted to understand and provide explanations for the drastic changes that took place during this time. Historical sociology is one of the earliest and most enduring forms of knowledge production, as it allows scholars to focus their attention on big questions about the nature of society, social processes, and social institutions over time. Some of the most significant scholarly works of the past century employ this method as they examine a range of topics including the rise of the welfare state, class formation, economic development, social revolutions and political organization. ${ }^{4}$ Studies in this tradition can be broadly interpretive or causal and analytical and can seek to make modest empirical claims and generalizations. These studies typically rely on a small number of cases, which allows for the kind of deep, contextualized analysis that is often lacking and

\footnotetext{
3 See Theda Skocpol, Sociology's Historical Imagination, in VISION AND METHOD IN HistoricAl SOCIOLOGY 1-21, (Theda Skocpol, ed., 1984).

${ }^{4}$ For an overview of major works, see chapters 2 through 10 in SKOCPOL, id.
} 
indeed often impossible in quantitative research, especially that which relies on cross-national comparisons based on statistical analyses. ${ }^{5}$

Based on this sociological approach, this article combines historical comparison with institutional analysis. The case comparison seeks to "explore alternative ways of establishing a meaningful dialogue between ideas and evidence, ${ }^{\prime 6}$ and the institutionalist approach examines relationships between state and society to see how patterns of behavior become structured and carried out by individuals and groups. ${ }^{7}$ As Theda Skocpol notes, "[B]ringing the state and state-society relationships to the fore in the definition of important, substantive problems for research, and in the search for explanatory hypotheses," has helped to identify "the interconnections of institutions and organizations that other scholars tended to treat separately from one another." 8 Within this institutionalist context, an emphasis on path dependency highlights

${ }^{5}$ See, e.g., SKOCPOL, supra note 4; JAMES MAHONEY \& DIETRICH RUESCHEMEYER, COMPARATIVE HiSTORICAL ANALYSIS IN THE SOCIAL SCIENCES (2003).

${ }^{6}$ Charles C. Ragin, The Comparative Method: Moving Beyond Qualitative AND QUANTITATIVE STRATEGIES viii (1987).

7 See, e.g., Charles Tilly, Big Structures, Large Processes and Huge Comparisons (1984); Kathleen Thelen \& Sven Steinmo, Historical Institutionalism in Comparative Politics, in STRUCTURING POLITICS: HistoricAl INSTITUTIONALISM IN COMPARATIVE ANALYSIS 1-32 (Sven Steinmo ed., 1992); Peter A. Hall \& Rosemary C.R. Taylor, Political Science and the Three New Institutionalisms, 44 POLITICAL STUDIES 936 (1996).

8 Theda Skocpol, Why I am a Historical-Institutionalist, 28 POLITY 103, 103 (Fall 1995). 
the temporal element of processes that often exhibit considerable stability until times of change, when decisions are made, paths are selected and alternatives are pushed aside. The goal is to formulate explanations for the development of state and social structures that reflect the instability of human relations and the fluid nature of socially constructed norms.

Thus, this study looks to the past to identify and examine the "critical junctures" or "switch-points" that led to certain communication policy outcomes. ${ }^{9}$ The path-dependent nature of media systems means that the outcomes produced at these critical junctures have a significant impact on a system's future. ${ }^{10}$ In the origins of broadcasting, we can see taking shape different modern conceptions of public and private, of individual and society, and of the proper role of the state. Today, similar policy debates surround regulation of the Internet and other digital technologies as we find ourselves in another critical juncture in communication history.

\footnotetext{
${ }^{9}$ See Giovanni Capoccia \& R. Daniel Kelemen, The Study of Critical Junctures: Theory, Narrative, and Counterfactuals in Historical Institutionalism, 59 WORLD POLITICs 341 (2007); Kathleen Thelen, Historical Institutionalism in Comparative Politics, 2 ANNUAL ReVIEW OF POLITICAL SCIENCE 369 (1999).

10 On path dependence, see PAUl PIERSON, POLITICS IN TIME: History, INSTITUTIONS AND SOCIAL ANALYSIS (2004); James Mahoney, Path Dependence in Historical Sociology, 29 THEORY \& SOCIETY 507 (2000); W. BRIAN ARTHUR, INCREASING RETURNS AND PATH DEPENDENCE IN THE ECONOMY (1994).
} 
This study also takes cues from critical and cultural studies in communication policy research, and follows the approach described by Willard D. Rowland Jr. ${ }^{11}$ Studies of communication and telecommunication policy and history often rely on "formalistic legal analysis of the relevant laws, administrative agency decisions, and judicial rulings with an emphasis on questions of constitutionality, process or precedence." 12 This study, like Rowland's, views policy debates and documents "as social and political texts subject to quite different readings, as socially created documents subject to interpretation in much the same way as are literary and other cultural texts."13 The historical comparative analysis of broadcasting origins presented here broadens Rowland's approach to include American and British life and, thus, centers on the state as the unit of analysis with attention to the legal codification of the public interest relevant to broadcasting policy and the institutional context for that development. Ultimately, this research aims to address a central question: How did different cultural conceptions of the "public interest" shape early broadcasting policy outcomes in the United States and Great Britain?

For this project, the collection of data was an iterative process between primary and secondary sources. There was also heavy reliance on secondary

11 Willard D. Rowland, Jr., The Meaning of 'The Public Interest' in Communications Policy, Part I: Its Origins in State and Federal Regulation, 2 COMM. L. \& POL’Y 309 (1997).

12 Id. at 313.

${ }^{13} I d$. 
sources in constructing a narrative surrounding the time period analyzed, perhaps more heavily than some historians would tolerate, but this is part of what makes the historical comparative approach possible. A large amount of data is needed to attempt to forge a comprehensive narrative and an adequate explanation for questions such as the ones at hand. For this reason, it is common for works of historical sociology to lean heavily on previous research in synthesizing explanations. As Skocpol argues:

[A] dogmatic insistence on redoing primary research for every investigation would be disastrous; it would rule out most comparativehistorical research. If a topic is too big for purely primary research - and if excellent studies by specialists are already available in some profusionsecondary sources are appropriate as the basic source of evidence for a given study. ${ }^{14}$

To be sure, this comparison of broadcasting origins is a big topic, and excellent studies by specialists are indeed available in profusion. I am fortunate to be able to make use of those works in the analysis that follows.

\section{SELECTION OF CASES}

14 Theda Skocpol, Emerging Agendas and Recurrent Strategies, in SКОСРОL, supra note 3, 382. 
Why does Great Britain provide a good comparison in understanding and explaining U.S. communication policy? What sort of comparative leverage is gained through this approach? For a successful comparative analysis, it is important to have an appropriate mix of similarities and differences. If cases are too similar or too different, comparative analysis can be ineffective in generating useful evidence and explanation. ${ }^{15}$ The British and American media systems are appropriate for comparative analysis due to an attractive blend of similarities and differences in both modern and historical incarnations. Other scholars have tended to agree, as historical analyses of one system often rely on comparisons with the other. ${ }^{16}$

Broadly, in their modern contexts, the British and American media systems are often considered quite similar when compared to those of the rest of the world. Both systems enjoy relatively similar press freedom and legal restrictions, and both systems exist within relatively similar market economies. ${ }^{17}$ As such, both systems fall within Daniel Hallin and Paolo Mancini's conceptualization of the "North Atlantic or Liberal" media system model, which contrasts with the "Polarized Pluralist Model" of the Mediterranean region and the "Democratic Corporatist Model" of north and central Europe. "The Liberal

\footnotetext{
15 See MAHONEY \& RUESCHEMEYER, supra note 5.

16 See, e.g., ERIK BARNOUW, A History OF BROAdCASTING IN THE UNITED STATES (1966); ASA
}

BRIGGS, THE History OF BROADCASTING IN THE UNITED KINGDOM (1961).

17 See HALLIN \& MANCINI, supra note 1. 
Model is characterized by a relative dominance of market mechanisms and of commercial media" even though there is "considerable variation among countries" grouped together..$^{18}$ In one of the central differences, public broadcasting in general receives a much larger audience share in the United Kingdom, where the organizational and institutional structure of the BBC and its long history helps to set the British media system apart.

Hallin and Mancini describe the British model for the regulation of broadcasting as the "professional model," in which "a strong tradition developed that broadcasting should be largely insulated from political control and run by broadcasting professionals." 19 Other broadcasting systems that exemplify this model include the Canadian Broadcasting Company, Irish public broadcasting, and some Scandinavian countries. Hallin and Mancini suggest that public broadcasting in the United States also fits within this model, but it is a much smaller part of the overall American media system as compared to the BBC in Britain. Of course, both media systems have experienced change over time. National public broadcasting did not exist in the United States until the 1960s, just as the British media landscape began to change in the 1950s with the introduction of commercial broadcasting and the Independent Television Authority, created by the Television Act of $1954 .{ }^{20}$ Today, both countries can be
${ }^{18} \mathrm{Id}$. at 11.
${ }^{19} \mathrm{Id}$. at 31.
20 TeleVision ACT OF 1954, 2 \& 3 ELIZ. 2, C. 55. 
characterized as mixed systems, although the American system remains much less mixed than the British.

In their historical contexts, the two countries share a common cultural heritage under the British crown, but the American Revolution also represents a significant departure from this heritage. ${ }^{21}$ The timeline is not the same, but both countries experienced relatively similar processes of democratization, and both countries experienced the Industrial Revolution in the nineteenth century, first in Britain then later in America, eventually giving rise to working and middle classes as well as similar social structures. ${ }^{22}$ Culturally, the late nineteenth century saw the growth of similar protectionist movements in both countries, as evidenced by Victorian ideals of service in Britain and Progressive Era reforms in the United States. ${ }^{23}$ And the long tradition of British paternalism, originating during the Tudor and Stuart eras, actually has a kind of analogue in American republicanism as espoused by such thinkers as Walter Lippmann. ${ }^{24}$ Politically, British parliamentary democracy is not the same as American republican democracy, but in that they are both Western, industrialized democracies, they

${ }^{21}$ See GORdON S. WOOD, THE RAdicALISM OF THE AMERICAN REVOLUTION 11-92 (1992).

22 See Philip Norton, The British POLITy (2nd ed. 1991); E. P. THOMPSON, THE MAKING OF THE ENGLISH WORKING CLASS (1964).

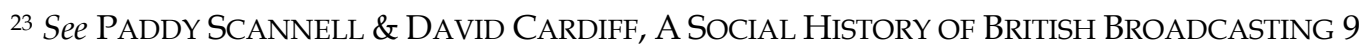
(1991). See also LeWIS L. GoUld, AMERICA IN THE PrOGRESSIVE ERA, 1890-1914 (2001).

${ }^{24}$ WALTER LIPPMANN, PUBLIC OPINION (1922). 
are appropriate for comparative analysis. With regard to media and communications, the two countries are historically similar in that they both developed similar publishing and telecommunication industries and experienced similar levels of press freedom. Generally, the United States and Great Britain and their respective media systems have an appropriate blend of similarities and differences in both their modern and historical contexts to make them well suited to comparative analysis.

\section{THE AMERICAN APPROACH: SERVING THE MARKET}

Much has been written about the history of both American and British broadcasting. ${ }^{25}$ Before Erik Barnouw's work in the 1960s, U.S. broadcasting histories often focused on the triumphs of industry and technology. ${ }^{26}$ Barnouw introduced the idea that the American commercial broadcasting system had "never been formally adopted." 27 This line of inquiry has since been pursued by a number of other scholars seeking to revise previously unquestioned accounts and incorporate critical analysis. Philip T. Rosen paid attention to the early battles over control for wireless technology that took place between the Navy, the Post Office and the Department of Commerce, and considered alternative

\footnotetext{
${ }^{25}$ See, e.g., BARNOUW, supra note 16; BRIGGS, supra note 16.

26 See, e.g., GLEASON L. ARCHER, History of RADiO TO 1926 (1938).

27 BARNOUW, supra note 16, at 281.
} 
types of broadcast systems that were clearly available as radio evolved. ${ }^{28}$ The late 1980s and 1990s brought a flurry of broadcasting histories, including Susan Douglas's important study of the period from 1899-1922, which brought to light the conflicting visions for broadcasting propagated in the press by inventors, amateurs and businessmen, who competed to have their visions dominate the popular imagination. ${ }^{29}$ Douglas concluded that this period is when the real debates over the structure of American broadcasting were settled, years before the first Radio Act was written into law. ${ }^{30}$

Thomas Streeter agreed with this assessment and built on the story by placing broadcasting in the context of corporate liberalism and clarifying the contradictions inherent in broadcast policy. ${ }^{31}$ He wrote:

The effort to create a free open marketplace has produced an institution that is dependent on government privileges and other forms of collective constraints. Although constructed in the name of the classical ideals of private property and the free marketplace, American commercial

28 PHILIP T. ROSEN, THE MOdERn STENTORS: RAdio BROADCASTERS AND THE FEDERAL GOVERNMENT, 1920-1934 (1980).

29 SUSAN J. DOUGLAS, INVENTING AMERICAN BROADCASTING, 1899-1922 (1987).

${ }^{30}$ Radio Act of 1927, Pub. L. 69-632, 44 Stat. 1162 (1927).

${ }^{31}$ STREETER, supra note 2. 
broadcasting, under close inspection, calls the coherence of those ideals into question. ${ }^{32}$

Susan Smulyan concentrated on the rise of commercialism from 1920 to $1934,{ }^{33}$ and Hugh Slotten argued that broadcasting had been viewed as a technical problem to be managed efficiently by the regulation of structure, not content or ownership. ${ }^{34}$ Slotten wrote: "Individuals were probably for the most part unaware that by applying technocratic principles to policy making about radio and television standards, especially by attempting to reduce issues to narrow technical facts, they were indirectly supporting corporate liberal principles." 35 Another major contribution came in the form of Robert W. McChesney's analysis of media reformers who, in the 1920s and 1930s, resisted the dominant approach to broadcasting and advocated for educational and noncommercial stations. ${ }^{36}$ His focus on the period from 1928 to 1935 suggests that the debates over structure were hardly settled until the commercial system was finally institutionalized in the Communication Act of 1934.

${ }^{32} I d$. at xii-xiii.

33 Smulyan, supra note 2.

${ }^{34}$ Hugh R. Slotten, Radio And Television Regulation: Broadcast TeChNOlogy in the UNITED STATES, 1920-1960 (2000).

${ }^{35}$ Id. at 237 .

${ }^{36}$ MCCHESNEY, supra note 2. 
Rowland's article in the Journal of Communication Law and Policy is perhaps most relevant here. Rowland describes the uses of the "public interest" standard in other applications prior to the advent of broadcasting and concludes that the standard always had a clear pro-industry meaning. ${ }^{37}$ When applied to broadcasting, the standard was intended first and foremost to protect the economic interests of private companies. The American approach to broadcasting "drew on the notion of natural monopoly" but "ensured that communication services would be commercial rather than governmental." 38 The Communication Act of 1934 would ultimately go out of its way to separate mass media and common carrier, where mass media would describe the private commercial operations that would dominate the airwaves and common carrier would be the classification for utility services such as the telephone that would provide equal access to all citizens. ${ }^{39}$

Despite evidence that seems to indicate an easy victory for industry forces in the battle to control radio, scholars have noted that it is actually remarkable that the United States was alone in the world in creating a private broadcasting

37 Rowland, supra note 11 , at 328.

38 PATRICIA Aufderheide, COMMUNiCATION POLICY AND THE PUbliC INTEREST: THE TELECOMMUNiCATIONS ACT OF 199614 (1999).

${ }^{39}$ This is the distinction between Title II and Title III, on which the current FCC's ruling on net neutrality hinges. The Internet remains classified as a mass medium rather than a common carrier, suggesting a preference to industry interests over public service. 
industry; in many other nations, the state retained control of the broadcasting system or created significant independent public broadcasting corporations. ${ }^{40}$ Yet since the origins of broadcasting, the intricacies of communications policy have come as much from business strategies as from government. ${ }^{41}$ Even in the early days of broadcasting, regulators were disinclined to regulate in order to avoid accusations of government censorship. ${ }^{42}$ In sum, media policy-making in the United States always has been an intensely political process with no guaranteed winners or losers.

\section{THE BRITISH APPROACH: “THE BRUTE ForCE OF MONOPOLY”}

Scholarship surrounding the history of British broadcasting almost cannot help but place itself in the context of American broadcasting, whether discussing similarities or differences. For example, Asa Briggs pointed out the contrast in the evolution of the two systems:

40 See Huseyin Leblebici, et al., Institutional Change and the Transformation of Interorganizational Fields: An Organizational History of the U.S. Radio Broadcasting Industry, 36 AdMIN. SCI. Q. 333 (1991); Herman S. Hettinger \& William A. Porter, Radio Regulation: A Case Study in Basic Policy Conflicts, 221 AnNALs of THE AM. ACAD. OF POL. \& Social SCI. 122 (1942).

41 See Harold D. Lasswell, Communications Research and Public Policy, 36 Pub. OPINION Q. 301 (1972); Jan van Cuilenburg \& Denis McQuail, Media Policy Paradigm Shifts: Toward a New Communications Policy Paradigm, 18 EUR. J. OF COMM. 181 (2003).

42 Erik Barnouw, Historical Survey of Communications Breakthroughs, 34 PROCEEDINGS OF THE ACAD. OF POL. SCI. 13, 16 (1982). 
Eventually the British and American broadcasting systems were to be so completely different - one based on a concept of "public service," the other fully integrated into the business system - that in all controversies about the place of radio in society they were to be taken as the two chief contrasting types. ${ }^{43}$

However, this was only true in the later years of the evolution. Earlier, the two systems were not so different. "In both countries there were the same pressures and the same outspoken advocates of common ideas and comparable institutions," ${ }^{44}$ Briggs wrote. Ultimately, the outcome in Britain was quite different.

John Reith led the British Broadcasting Company from its origins as a heavily regulated private monopoly in 1922 through its shift to a public corporation operating under royal charter in 1927. Until he stepped down in 1938, he was perhaps the lead proponent of or at least the best known advocate for the preservation of a noncommercial system of broadcasting in Britain. In a 1949 Report of the British Broadcasting Committee, Reith articulated the manner in which this preservation was accomplished:

\footnotetext{
${ }^{43}$ BRIGGS, supra note 16 , at 59 .

${ }^{44} I d$.
} 
It was the brute force of monopoly that enabled the BBC to become what it did, and to do what it did; that made it possible for a policy of moral responsibility to be followed. If there is to be competition it will be of cheapness not of goodness. The usual disadvantages and dangers of monopoly do not apply to Broadcasting; it is in fact a potent incentive. ${ }^{45}$

The "brute force" employed by the leaders of the BBC was their solution to the paradox of democracy, in which rational, informed policies and practices can be difficult to come by when irrational, uninformed approaches to problems carry just as much weight.

Reith sought to reconcile this dilemma, and his approach to democracy that earned him and the $\mathrm{BBC}$ charges of elitism and paternalism:

There must be some principle of ethics or economics to justify equality of electoral power to an intelligent, responsible, respectable citizen, a producer by hand or brain, contributor in large or small measure to the wellbeing and wealth of the State; and to another unintelligent, irresponsible, a lifelong charge on the State. ${ }^{46}$

45 Report of the Broadcasting Committee 1949: Appendix H: Memoranda submitted to the Committee 364 (Cmd. 8117) (quoted in Burton PAUlu, BRITISH BROADCASTING 18 (1956)).

${ }^{46}$ JOHN C.W. REITH, INTO THE WIND 170 (1949). 
It is easy to see how Reith could be viewed as an elitist, but it is this approach that governed the BBC at least until the introduction of commercial television in Britain in 1955. Even after the emergence of competition and the Independent Television Authority, the BBC continued and continues to lead as one of the world's foremost broadcasting institutions.

While it is tempting to think of Reith's approach as more noble than that of the American system, Burton Paulu suggests that it is important not to think of either system as superior:

Both the critics and the admirers of the British system overlook one very important fact: a broadcasting system grows out of its environment and cannot be described or appraised apart from its national setting. Above all, it cannot be judged on the basis of how it might function in another country. 47

Paulu suggests that the British system is unfathomable to Americans because of the potential for government control. But this neglects the fact that government control was not a totally foreign concept in the United States; in fact, it had long been present in daily life in America in such forms as public schools, the Post Office and the military. Further, government control of radio actually was a

\footnotetext{
47 PAULU, supra note 45 , at 3-4.
} 
distinct possibility in the United States well into the 1920s. ${ }^{48}$ Paulu also points out that even without government control of broadcasting, critics warn of government influence in the American system just as much, if not more, than in the British system. ${ }^{49}$

James Curran and Jean Seaton suggest that the development of British broadcasting has been described in two ways. ${ }^{50}$ One view is that the emergence of the BBC monopoly was the "personal achievement" of John Reith, who embarked on a cultural mission and succeeded. The other view is that the emergence of the monopoly was accidental, or at least was a mere bureaucratic solution crafted by the Post Office to deal with what was viewed as a technical problem. ${ }^{51}$ R. H. Coase sides with the latter view, pointing out that radio was developed faster and with better results in the United States..$^{52}$ More experimentation took place in the United States because people were eager to sell wireless receivers and set up commercial broadcasting services. The British Post Office, which already controlled all wireless and telephone communication, was not prepared to issue broadcasts and thus had no incentive to encourage

48 ROSEN, supra note 28 , at $15-33$.

${ }^{49} \mathrm{Id}$. at 42 .

50 JAMES CURRAN \& JEAN SEATON, POWER WITHOUT RESPONSIBILITY: THE PRESS AND BROADCASTING IN BRITAIN 103 (5th ed. 1997).

${ }^{51} I d$.

52 R. H. COASE, BRITISH BROAdCASTING: A STUDY IN MONOPOLY (1950). 
experiments. ${ }^{53}$ Furthermore, based on the U.S. experience, British officials thought a monopoly was necessary to avoid interference problems. ${ }^{54}$ Coase acknowledges that there was a unique public service mission in the United Kingdom but suggests that this is only part of the story. Paddy Scannell and David Cardiff suggest that there is truth in all of these understandings and that the public service mission came after the monopoly had been established for technical purposes. 55 "Public service was a concept grafted onto an initial pragmatic set of arrangements between the Post Office and the British radio industry to establish a broadcasting service that would create a market for radioreceiving apparatuses,"56 they write.

Other countries were guided by the alternative approaches in the United States and Britain. Canada, for example, followed the United States at first, allowing private, commercial stations, but then created a national public broadcasting commission in 1932, which became the Canadian Broadcasting Corporation in 1936. Private stations remained, however, resulting in a hybrid model of public and private broadcasters. ${ }^{57}$
${ }^{53} \mathrm{Id}$.
${ }^{54} \mathrm{Id}$.
55 SCANNELL \& CARDIFF, supra note 23.
56 Id. at 5.
57 See Paul W. Newsbitt-Larking, Politics, Society AND the Media: CANadian

PERSPECTIVES 49-74 (2001). 
In Britain, public service broadcasting had a solid footing, benefited from public support, and gained a complete monopoly over broadcasting from the 1920s until the 1950s. The BBC retained a commitment to public service even after the introduction of commercial radio and television. Regulations made it difficult for commercial broadcasters to dominate the market and established standards requiring them to serve the public interest. ${ }^{58}$ "In short, commercial principles were kept on a short leash and were not permitted to set the rules for the entire system," 59 one scholar writes.

The success of the $\mathrm{BBC}$ in preserving national traditions and culture also has invited harsh critiques from both the left and the right. Critics charge that despite efforts to insulate the $\mathrm{BBC}$ from political influence, the institution narrowly represents the interests of the dominant class. As one British scholar has noted, "In actual fact the largeness and wealth of the BBC indicate precisely its willingness to incline to the wishes of the powerful. If it posed the slightest threat to the powerful it would be dismantled." 60 It is worth noting that a similar

\footnotetext{
58 Robert W. MCCHESNey, Rich Media, POOR DEMOCRACY 249 (1999).

${ }^{59} \mathrm{Id}$.

${ }^{60}$ William Maley, Centralisation and Censorship, in THE BBC AND PUBLIC SERVICE
}

BROADCASTING 41 (Colin MacCabe \& Olivia Stewart eds., 1986). 
critique has been applied to American commercial media, in that news outlets can be said to reflect the ideology of their capitalist owners. ${ }^{61}$

Scholars point out that, in Britain today, the long-established licensing fee and the culture it perpetuates are the central reasons for the BBC's ability to produce what is often considered to be high-quality content. ${ }^{62}$ This paints a portrait of a quite different media culture for Britain compared to what originated in the United States and remains present today.

\section{CONTEMPORARY CONTEXT I:}

\section{THE RISE OF THE MARKET ECONOMY AND STATE CAPITALISM}

To understand the context in which broadcasting policy developed, it is important to consider the rise of market economies in the nineteenth century, which caused major transformations in society. The idea of the classic market economy, with free trade in land, labor and capital, never actually came to be, as described by Karl Polanyi, William M. Reddy and others. ${ }^{63}$ What did transpire,

${ }^{61}$ See, e.g., EDWARD S. HeRMAN \& NOAM CHOMSKY, MANUfACTURING CONSENT: THE Political ECONOMY OF THE MASS MEDia (2002).

62 See LuCy Kung, INSIDE CNN AND THE BBC: MANAGING Media ORGANIZATIONS 136 (2000).

${ }^{63}$ Karl Polanyi, The Great Transformation: The Political and ECONOMic ORIGins of Our Time (2nd. ed., 2001); William M. Reddy, The Rise of MARKet Culture: The TeXtile Trade AND FRENCH SOCIETY, 1750-1900 (1984). 
as Reddy suggests, was the rise of a "market culture," or a set of incorrect perceptions and misguided practices that were informed by the language and ideas of classic market economics but were never reflected in reality. ${ }^{64}$ Regardless of its level of adherence to the rules of capitalism, this market culture, in both the United States and Europe, "sparked countermovements of protest, reform, and public regulation, all attempting to control the unsettling effects of economic upheaval." 65 This was especially true in Britain, which has been called the first industrialized nation and the first to have an established working class, which emerged around the mid-eighteenth century ${ }^{66}$ The British Empire was growing to cover a quarter of the planet, but the expectations for government were beginning to change to reflect needs beyond those of the national defense. The expansion of government was "attributable to the increasing demands and expectations of the newly enfranchised working population. Government began to conceive its duties as extending beyond those of maintaining law and order and of defending the realm." ${ }^{\prime \prime 7}$ These new measures enacted in the nineteenth century included efforts to improve working conditions and public health, and were "within the capabilities of the government to provide. They did not create

\footnotetext{
${ }^{64}$ REDDY, supra note 63.

${ }^{65}$ STARR, supra note 1 , at 233.

${ }^{66}$ See NORTON, supra note 22; THOMPSON, supra note 22.

${ }^{67}$ NORTON, supra note 22, at 52.
} 
too great an economic burden; they were not themselves economic measures." 68 Concern for public welfare began to grow in the mid-1800s and remained a largely nonpolitical issue well into the twentieth century. ${ }^{69}$ Protective measures were put into place by conservatives and liberals as the welfare state grew and the British Empire shrank. Attention was increasingly paid to domestic needs, especially during the interwar period. In this context, the British Parliament was designed to facilitate cooperation during the political process and to accommodate citizen input. ${ }^{70}$

This is also the context in which the paternalism of John Reith's BBC likely grew. Since the Tudors and Stuarts, who heavily regulated what industry and commerce existed at the time, ${ }^{71}$ Britain has a long history of paternalism, the effects of which can be seen well into the 1800s. Historically, this notion of paternalism described the relationship of the aristocracy to the working class; it was thought that the privileged members of society owed some duty to the lower classes, which needed to be cared for both economically and culturally. This paternalism manifested itself, in part, in the protectionist measures instituted in

${ }^{68} \mathrm{Id}$.

69 See BriAn HowARd HARrISON, THE TRANSFORMATION OF BRITISH POLITICS, 1860-1995 (1996).

${ }^{70} \mathrm{Id}$. at $55-84$.

${ }^{71}$ See A.I. Ogus, Regulatory Law: Some Lessons from the Past, 12 LEGAL STUDIES 1 (1999) (quoted in Mike FeintucK, “The Public InTERest” in Regulation 36 (2004)). 
response to the Industrial Revolution. Polanyi's "double movement" concept describes the way in which British society was pulled in separate directions, which he called expansionism and protectionism. ${ }^{72}$ As markets grew during the Industrial Revolution, government sought to facilitate economic growth but to keep the pace slow enough as to protect citizens from the negative effects of emerging markets. Self-interest was restrained to some degree in order to serve larger social aims. Philip Norton describes this pattern of British history:

The reforms of the nineteenth century were facilitated not only by an empirical orientation to change but also by the paternalism of political leaders. Noblesse oblige (privilege entails responsibility) is a foreign phrase but it embodies a very British concept. Many of the country's aristocratic leaders believed that they had a duty to help improve the condition of the working man. ${ }^{73}$

This was far less so in America, where the revolutionary, republican spirit still filled society with a preference for individualism and independence over state intervention. As Michael Schudson notes, the increasing "democratization

\footnotetext{
72 POLANYI, supra note 63, at 136.

${ }^{73}$ NORTON, supra note 22, at 57.
} 
of economic life" stressed economic gain "to the exclusion of social aims."74 This blurred distinctions of class in what Schudson calls "the egalitarian age," a period in the 1830s and 1840s that saw "the opening of opportunity to persons regardless of birth or breeding." 75 The spread of public education during this time brought with it a spreading of wealth and political power, and "economic development was promoted and shared by many rather than by few." 76 Penny papers contributed to the expansion of the market through increased advertising thus enlarging the market for manufactured goods and by transforming the newspaper into a consumable product for private home use, not just borrowed or passed around in public. ${ }^{77}$ This all speaks to the rise of a market culture in the early United States that was somewhat closer to classic market ideal than the market culture in Europe. As Schudson writes, "It became more acceptable to think of 'self-interest' as the mainspring of human behavior and, indeed, in the theory of the market, as a motive to be admired, not distrusted."78 Thus, it was during this period and the decades that followed that notions of democracy and personal freedom and equality became tied to economic self-interest. The

${ }^{74}$ Michael SCHudson, Discovering THE News: A SOCiAl History OF AMERICAN

NEWSPAPERS 46 (1978).

${ }^{75} \mathrm{Id}$. at 44 .

${ }^{76} \mathrm{Id}$. at 45.

${ }^{77} \mathrm{Id}$. at 46.

${ }^{78} I d$. at 58. 
capitalist pursuit of wealth was becoming synonymous with democracy itself. The regulatory framework that made this shift possible has been described as capitalist state theory, in which a structural bias resulting from the state's interest in economic growth leads to policies that prop up dominant capitalist actors. ${ }^{79} \mathrm{~A}$ history of paternalism and protectionism meant that Britain was more able to resist this approach, while the United States would embrace it.

\section{CONTEMPORARY CONTEXT II: THE PRESS AND COMMERCIALIZATION}

It was also in this context that the notion of press freedom formed in the American colonies; the main threat to free speech was thought to be from government, Paul Starr wrote:

Precisely because of the interest in strengthening republican institutions, early American policy included strong positive commitments to information and communications, not merely the "negative liberty" of individual rights to free expression. While the Europeans taxed publications, the United States subsidized the growth of independent newspapers through cheap postal rates. ${ }^{80}$

\footnotetext{
79 See Robert B. Horowitz, THE IrONy OF RegUlatory REFOrM 41 (1989).

80 STARR, supra note 1 , at 16.
} 
While the First Amendment expresses an essentially negative conception of liberty based on broad libertarian ideals ${ }^{81}$ press freedom in practice relied on the positive commitments described by Starr. In the early- to mid-1800s, printers were typically aligned with political organizations, and the content of their publications was generally partisan and advocacy-oriented. This is not surprising, as funding came from political organizations, but it also came from government, which subsidized the early press through printing contracts and other means. ${ }^{82}$

News began to see a shift in the mid-1800s as capitalism was born and the press began to commercialize. ${ }^{83}$ Gerald Baldasty documents the American "evolution of news as a commodity to be shaped and marketed with an eye for profit" 84 as a phenomenon that began in the nineteenth century as newspapers shifted away from partisanship toward objectivity. While the partisan press was heavily influenced by political interests, it is important to note that its main goal was to provide information, advocate for causes, and support candidates for

81 See JeFFERy AlAN SMITH, PRINTERS AND PRESS FrEEDOM: THE IDEOLOGY OF EARLY AMERICAN JOURNALISM (1988).

82 See Richard B. Kielbowicz, News in the Mail: The Press, Post Office ANd Public INFORMATION, 1700-1860S (1989); ROBERT MCCHESNEY \& JOHN NICHOLS, THE DEATH AND LIFE OF

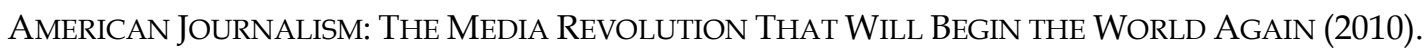

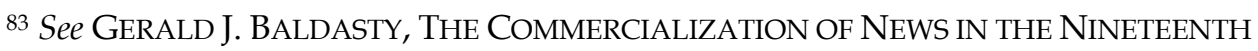
CENTury (1992).

${ }^{84} I d$. at 4 . 
office. Newspapers did not operate for profit, and they stressed news and politics over entertainment and gossip. Before the commercialization of news, partisan newspapers were part of the political process and produced a range of debate about contemporary issues. This began to change as publishers realized they could make a profit by neutralizing content, reaching wider audiences, and selling space to advertisers. It is in the period after the Civil War that advertising began to take its modern form, shifting from dry, fact-based claims to a reliance on slogans and images. ${ }^{85}$

Thus, the rise of the penny press brought with it a decline in interest in and attention to politics and a rise in attention to business and the general commercialization of society. "The rise of the penny press, as limited geographically as those cheap and lively papers were, provided the basis for the press as a servant of business rather than of politics," 86 Baldasty wrote. Rather than advocating for political goals and participating in the political process, the press shifted its focus to providing entertaining and sensational fare that would attract large audiences, large circulations, and large revenues from advertisers. Success was measured by "news gathering and scoops, by ever-growing circulation, and by booming revenues. Public service was second to private

85 See INGER L. STOLE, ADVERTISING ON TRIAL: CONSUMER ACTIVISM AND CORPORATE Public ReLATIONS IN THE 1930s (2006).

86 BALDASTY, supra note 83 , at 37. 
gain." 87 Advertisers began to counsel newspapers on the type of content that would be attractive to business. Successful papers would avoid politics, especially criticism of government officials, would be "optimistic and happy about the world" and "present the bright side of life," and offer "something of interest to everyone in the potential reading audience, but particularly to women." 88 This shift also required increasing attention to demographics so that news content could be designed to attract consumers who could purchase the goods and services being advertised. ${ }^{89}$

So while the rise of advertising during the nineteenth century helped free the commercial press from government and political parties, new structures and limitations were put in place. Rather than being tied to political ideologies, the press became tied to one dominant ideology of commercialism and market values. Schudson describes this as a shift to "the culture of a democratic market society, a culture which had no place for social or intellectual deference. This was the groundwork on which a belief in facts and a distrust of the reality, or objectivity, of 'values' could thrive." 90 The penny papers, from which modern journalistic values were drawn, were guided by and helped to institutionalize the emerging ideology of commercialism with its focus on economic growth. This
${ }^{87} \mathrm{Id}$. at 47.
${ }^{88} \mathrm{Id}$. at 78.
${ }^{89} \mathrm{Id}$. at 114 .
${ }^{90}$ SCHUDSON, supra note 74, at 60. 
shift laid the groundwork for the commercialization of broadcasting in the coming century in the United States. In Britain, it is exactly this approach to media content that John Reith and the BBC would later resist, electing to ignore audience demands or at least balance them with content that reflected the high culture of the British elites.

The commercialization of the American press in the mid-1800s would have parallels in Britain, where these new pressures "introduced a new system of press censorship more effective than anything that had gone before. Market forces succeeded where legal repression had failed in establishing the press as an instrument of social control." 91 The reaction was the emergence of a radical, working class press that would thrive in the 1800s and then decline with the increasing commercialization and industrialization of British life, the rise of the middle class, and the lifting of stamp and paper taxes, or the "taxes on knowledge." The lifting of taxes was not meant as a gift to publishers or readers, but rather as a shift away from state regulation to regulation by market forces. “The parliamentary campaign for a free press was never inspired by a simple libertarian commitment to diversity of expression," scholars wrote. "All that had changed was an increasing conviction that market forces were a more efficient and morally preferable control system to that administered by the state." 92 In Britain as in America, the commercialization of the press helped to create mass

\footnotetext{
${ }^{91}$ CURRAN \& SEATON, supra note 50, at 17.

${ }^{92} \mathrm{Id}$. at $41-42$.
} 
audiences and mass markets, in which the press and advertising soon became dependent on each other..$^{93}$

Thus, the shifts in press structure in the United States and Britain in the nineteenth century show far more similarities than the structures chosen for any of the electronic communication technologies that emerged later. These early similarities emphasize the nature of broadcasting origins as a critical juncture, where links in the chains of communication history were clearly broken as the two countries diverged sharply from what had previously been similar social contexts. At the same time, these early similarities helped define the paths available to the actors who created broadcasting policy.

\section{CONTEMPORARY CONTEXT III: THE POST OFFICE AND THE TELEGRAPH}

The revolution brought by the wired electric telegraph in the 1840s cannot be understated, as it separated communication from transportation for the first time in human history, as James Carey noted..$^{94}$ The new communication technology quickly evolved in very different ways in the United States and Europe. ${ }^{95}$ As Paul Starr notes:

93 BRIGGS, supra note 16 , at 42.

94 JAMES W. CAREY, COMMUNiCATION AS CUlture: ESSAYS ON MEDIA AND SOCIETY (1989).

95 STARR, supra note 1 at 153-155; RICHARD R. JOHN, NETWORK NATION: INVENTING AMERICAN TELECOMMUNICATIONS (2010). See also ROBERT L. THOMPSON, WiRING A CONTINENT: THE HiSTORY OF THE TELEGRAPH INDUSTRY IN THE UNITED STATES, 1832-1866 (1972); Joshua D. Wolff, 
In Europe, the domestic telegraph, and later the telephone, came under the control of the state and were often assimilated into the organization of the postal system. In the United States, in contrast, both the telegraph and the telephone were established as private enterprise and went through a phase of intense competition before evolving into monopolies and becoming subject to government regulation. ${ }^{96}$

These early outcomes related to regulatory control constituted new and different understandings of the role of the state in regulating industry in general and communication in particular. In terms of path dependence, the contested policy decision in America created inertia and feedback through the removal of options over time. It also helped to write the scripts that future policymakers would rely on in promoting industry power over government control in communications. Had the United States opted for a government buyout of the telegraph companies as Britain did, American radio policy might have seen an entirely different fate.

Thus, the birth of the telegraph represents a critical juncture of its own, and it initiated path-dependent processes that would carry well into the

\footnotetext{
“The Great Monopoly": Western Union and the American Telegraph, 1845-1893 (Ph.D. dissertation, Columbia University 2008).

96 STARR, supra note 1, at 153-155.
} 
twentieth century and affect the structure of broadcasting in both nations in the 1920s and 1930s ${ }^{97}$ But these processes were affected by more than mere matters of ownership and control. Broader economic, legal and cultural conditions affected the development of the new technology. The regulatory environment in the U.S. encouraged the development of industry and technology more than in Britain, as Starr notes:

American law and policy, as well as other conditions, were more favorable to telecommunications development and led to more rapid, early deployment of the technologies. Indeed, Americans played more of a pioneering role in developing both the telegraph and the telephone than one might reasonably have expected from the country's overall level of industrial and scientific development in the mid-nineteenth century. ${ }^{98}$

The centralized nature of the economy in the early American republic, which presupposed a government takeover of the telegraph, eventually came into conflict with a "state-oriented political economy that encouraged competition between rival telegraph network providers chartered as private corporations." 99 In spite of this competition in the race to develop the first telecommunications
${ }^{97} \mathrm{Id}$. at 189.
${ }^{98}$ Id. at 154.
${ }^{99}$ JOHN, supra note 95 , at 8 . 
network, Western Union gained control of the telegraph industry in the 1840s, and the Associated Press dominated wire service news. These monopolies represented "a new form of centralized power" for which Americans "at first had no institutional response." 100 Western Union was subject to more government regulation than other business operations, ${ }^{101}$ but it still gave preference to business correspondence over personal messages, and its collusion with the Associated Press made it difficult for smaller, local wire services to exist. This provided a sharp contrast to the telegraph service that was provided by the British Post Office, which treated the technology as a public utility and a nationalized monopoly. It was not until the late nineteenth century in America that concerns about private monopoly power grew and regulation of industry became acceptable. This would be evident with the trust-busting of presidents Theodore Roosevelt (1901-1909) and William Howard Taft (1909-1913).

This is not to suggest that Americans did not debate the private monopoly held by Western Union in the nineteenth century. Wolff characterizes the rise of Western Union as America's first national corporate monopoly as a "traumatic transition" from the tradition of public ownership in the postal system. ${ }^{102}$ This took place in spite of intense public, state and commercial opposition, and

100 STARR, supra note 1 , at 16.

101 CHARLES H. TILLINGHAST, AMERICAN BROADCAST REGULATION AND THE FIRST

AMENDMENT: ANOTHER LOOK 18 (2000).

102 WOLFF, supra note 95. 
represented a shift away from traditional concerns for the public interest. As early as 1845, The New York Herald had called for the federal government to "undertake the arrangement," suggesting that the "public interest" would be "much more securely promoted" in the hands of government. ${ }^{103}$ Similarly, an 1868 article in The New York Times summarized a report advocating for uniting the post office and the telegraph in the United States, as had been done in Britain and much of Europe. The report by Massachusetts lawyer Gardiner G. Hubbard described the situation in Europe and "gives evidence of the fact that where the Government owns the telegraph and unites it with the Post Office the wants of the public are far better supplied than where the lines are owned and operated by individuals or companies."104

By the 1880s, many Americans were hopeful for a government takeover of the telegraph. As John notes, "In no other decade did so many journalists, lawmakers, and telegraph users invest such high hopes in the establishment of a government telegraph. And in no other decade did they come away more disappointed."105 The closest Congress came was with the Post Road and Telegraph Act of $1866,{ }^{106}$ which was designed to restrict Western Union and made provisions for a possible Congressional buyout of existing telegraph

${ }^{103}$ Electric Telegraph, N.Y. HERALD, Apr. 22, 1845 (quoted in JOHN, supra note 95, at 55).

104 The Post Office and the Telegraph, New York Times, Nov. 25, 1868.

${ }^{105} \mathrm{JOHN}$, supra note 95, at 172.

106 Post Road and Telegraph Act of 1866, 14 Stat. 221, c. 230. 
corporations. The passage of the act and the nearly simultaneous nationalization of the British telegraph spurred many calls for a government takeover in the United States, such as one by Missouri Senator B. Gratz Brown. Contending that competition was not working in the telegraph industry, Brown proposed that a government telegraph would, like the postal service, better serve rural areas and would break up the "collusive relationship" between the telegraph corporations and the Associated Press. ${ }^{107}$ This takeover never happened, and political economists in the late 1800s introduced the idea that the telegraph represented a "natural monopoly," an idea that could be used to justify private ownership by a single company, but could also be used as a call for more effective federal government control. ${ }^{108}$ This sort of debate foreshadows what was about to become the central question surrounding the emergence of broadcasting.

The American tolerance of the Western Union monopoly contrasts sharply with the British approach to the telegraph. While the British state eventually relinquished direct control of the publishing industry, new communication technologies did not share the same fate. The rise of the telegraph in the mid1800s led to the Telegraph Act of $1869,{ }^{109}$ which gave the Post Office the

\footnotetext{
107 JOHN, supra note 95, at 121.

108 JOHN, supra note 95, at 157.

109 Telegraph Act of 1869, 32 \& 33 Vict., c. 73.
} 
exclusive right to transmit telegrams within the United Kingdom. ${ }^{110}$ Prior to the act, several private telegraph companies operated in the United Kingdom, including the Electric and International, the British and Irish Magnetic, and the United Kingdom Telegraphy Company. Fixed prices were set in 1865, several years before the transition to full public monopoly. (This transition from regulation of private industry to total public ownership would later be mirrored in the shift from the British Broadcasting Company to the British Broadcasting Corporation in the 1920s.) In addition to inconsistent pricing, the public had also complained about poor service, especially in rural areas. These complaints from the public fueled the drive for nationalization in the public interest. ${ }^{11}$

Despite the complaints, even before the postmaster general was empowered by Parliament to purchase the private holdings, the telegraph service was a popular means of communication among ordinary citizens, as compared to America's Western Union, which mostly existed to serve business communication needs. In 1868, the average Western Union toll was $\$ 1.05$, about two-thirds of what an American worker earned in a day. ${ }^{112}$ By 1870, the British and American services each sent about ten million messages per year, but the United States had twice the population of Britain. The British service transmitted

110 See ANDREW CRISELL, AN INTRODUCTORY HISTORY OF BRITISH BROADCASTING (2002);

Joseph C. HeMmeOn, THE History OF THE BRITISH POSt OfFiCE (1912).

111 CRISELL, supra note 110.

112 See WOLFF, supra note 95 , at 9. 
thirty-three million messages in 1884-85 and fifty million messages in 18861887.113 Commercial and speculative messages provided $87 \%$ of the Western Union's revenue in 1887, according to a report from Western Union to the U.S. Postmaster General. The report said only 2\% of Americans used the telegraph each year, and only $5 \%$ of the company's revenue came from "family and social messages."114 According to Wolff, "To Western Union, the telegraph was first and foremost an adjunct of commerce, and speed was more important than price. As long as the principal customers of the telegraph were in businesses that demanded high-volume, high-speed communication, Western Union's network was 'best.'" 115 This characterizes the opposite of what was expected from public service utilities operating in the public interest. Reformers who opposed the Western Union monopoly "envisioned a low-priced telegraph that would be used by all Americans, and while many reformers claimed that such a system would be at least break-even, some admitted that even at a loss it was a cost worth bearing." 116

The British telegraph in the hands of the post office was never profitable, partly due to management problems and partly due to competition from

113 See HEMMEON, supra note 110, at 210.

114 See WOLFF, supra note 95, at 4.

$115 \mathrm{Id}$. at 8 .

116 Id. 
telephone and improved postal services. ${ }^{117}$ So neither the British nor the American telegraph services were successful in the sense that neither was able to serve a broad citizenry and remain profitable. But it certainly is clear where their priorities lay. The American system served American business at a high cost and a large profit; the British system served the public at a low cost even while operating at a loss. And despite their shortcomings, both of these distinct approaches to regulating communication technology would be repeated to some degree by each respective country, first with the telephone and later with broadcasting.

Especially in Britain, the early decision to maintain government control over wired transmissions had a lasting effect. An 1880 court case established the post office as the universal licenser of wired phone services, ${ }^{118}$ and a 1904 act gave the Postmaster General control of wireless telegraphy and later all telephony. ${ }^{119}$ Ultimately the post office became the licenser of "broadcast wireless telephony" and the sole operator of broadcasting, as it began to compete with its own licensees and established a near monopoly by taking over trunk lines and refusing to extend local licenses until after 1911. Telephony remained a public monopoly under the post office until 1984 when it was privatized as

117 HEMMEON, supra note 110, at 218.

118 A. N. HOLCOMBE, The Telephone in Great Britain, 21 QUARTERLY JOURNAL OF ECONOMICS 96, 99 (1907).

119 CRISELL, supra note 110, at 12; STARR, supra note 1, at 340. 
British Telecom. The United States, on the other hand, would allow its telephone service to operate as a private, regulated near-monopoly, and would leave broadcasting in the hands of industry, which by the turn of the century, was a whole new force in society. ${ }^{120}$

In sum, Britain and the United States experienced relatively similar processes of commercialization in their press structures in the nineteenth century, setting the stage for divergent approaches to broadcasting. But the divergent approaches are less surprising considering the path-dependent processes initiated during the emergence of the first electronic communication forms in the mid-1800s. Britain viewed competition in the telegraph industry as problematic and chose to nationalize and improve the service, which was popular among the public even before the government buyout of industry. Despite widespread protests, the United States tolerated the Western Union monopoly, preferring a veneer of regulatory control to any sort of government takeover. In both countries, the debates over the regulation of telegraphy would be echoed in the debates over broadcasting, as similar policy scripts would be invoked by subsequent historical actors. The policy outcomes would also be echoed, suggesting that causal chains were being laid even if the links would later be broken, if only for a short time. And although the public interest may not have been explicitly invoked in communication policymaking at this critical

120 See Roland Marchand, Creating the Corporate Soul: The Rise of Public

RELATIONS AND CORPORATE IMAGERY IN AMERICAN BIG BUSINESS (1998); STOLE, supra note 85. 
juncture, the different approaches to the telegraph likely influenced what different meanings the public interest would take on when it was invoked later.

\section{THE RADIO EXPLOSION IN AMERICA}

At the start of the 1920s, the conditions of radio in the U.S. and Britain were not so different. In the United States, the Navy was poised to retain control over coastal operations following World War I, and the Department of Commerce would issue licenses to amateurs and the handful of private stations that requested them. ${ }^{121}$ In Britain, the post office retained control of the airwaves and licensed a handful of radio manufacturers to make their own broadcasts. ${ }^{122}$ Demand was low, broadcast signals could not travel far, and the situation was relatively stable. But advances in technology and in imagination had given birth to the possibility of broadcasting as a form of mass communication, and radio manufacturers were eager to see their new crystal set receivers in every household. Stimulating this sort of mass demand required programming, and as radio grew, there was no shortage of groups of people - from newspapers, department stores and other businesses to universities, churches and political groups - who wanted to make their voices heard. ${ }^{123}$ Spectrum scarcity - the limited physical property of the airwaves - demanded some system of control,

\footnotetext{
121 ROSEN, supra note 28 , at 15-33.

122 CRISELL, supra note 110, at 13.

${ }^{123}$ BARNOUW, supra note 16 , at 4 .
} 
but the sudden boundless enthusiasm to hear and be heard challenged efforts to regulate the new technology.

The wartime ban on amateurs receiving wireless signals was finally lifted by the Navy on April 12,1919, and the ban on transmitting was lifted September 26. ${ }^{124}$ The Department of Commerce licensed thousands of amateur operators in 1920 and 1921, but the amateurs, despite their advanced knowledge, were slow to gain access to the new technologies that would allow them to send and receive speech and music. They were also relegated to the amateur range of frequencies so as not to interfere with the growing number of private businesses operating their own licensed stations, such as department stores and newspapers. It is tempting to describe these stations as "commercial," and they were in the sense that they were operated by private businesses, but there was no paid advertising on the airwaves at this point. Rather, for a station run by a department store or newspaper, for example, "the entire station was an advertisement." 125 “Toll” advertiser-supported broadcasting, or "commercial" broadcasting in the modern sense, would not come along until 1922, and it would be slow to catch on. Nevertheless, as the struggle for the airwaves continued, the amateurs did not always comply with warnings from the Department of Commerce to stay in their range. But once the amateurs were back in the radio game, Westinghouse

124 This story is told in BARNOUW, supra note 16, at 39-74; DOUGLAS, supra note 29, at 292315; ROSEN, supra note 28, at 15-33.

125 STARR, supra note 1 , at 336. 
executives realized what they were missing out on. They had failed to understand the true potential and meaning of radio. Westinghouse scrambled to build a new transmitter at its plant in Pittsburgh and applying to the Department of Commerce for a special license to launch a regular broadcasting service with the goal of stimulating sales of receivers. The company received the call letters KDKA, and on November 2, 1920, made what is usually considered the first mass radio broadcast of significant strength as they read election returns over the air. $^{126}$

Over the next year, amateur operators started lining up to purchase the radio sets made by hobbyists and sold by department stores, some of which started their own radio departments. In 1921, Westinghouse aligned with General Electric, RCA and AT\&T to share a pool of patents and trademarks and began manufacturing radio sets. ${ }^{127} \mathrm{GE}$ and Westinghouse manufactured radio sets and parts while RCA marketed and sold them, and AT\&T handled transmitter equipment. Towers went up all over the country; amateurs did whatever they could to circumvent the four radio giants. These four companies formed the radio trust that would come to dominate what can only be loosely described as an "industry" over the next few years and receive licenses for the preferred high-power bands of the spectrum. Despite the growth of the radio trust, "the industry" was still a diverse mix of interests, including everyone from

\footnotetext{
${ }^{126}$ ROSEN, supra note 28 , at 7.

127 BARNOUW, supra note 16 , at 61-74.
} 
RCA to universities to churches to political groups. Amateurs and others also inundated the Department of Commerce for private business licenses to broadcast on the better, clearer frequencies. And although Secretary of Commerce Herbert Hoover had been granted the power to issue these licenses under the 1912 Radio Act, ${ }^{128}$ he had no power to deny them. Under these conditions, chaos was inevitable. Broadcasting presented a unique challenge in America, in that it "did not lend itself to any of the older forms of government supervision. ... Regulation and standardization therefore were necessary but impossible within the framework of existing institutions."129

The battle for control raged. In January 1922, the Department of Commerce ordered all amateurs to stop broadcasting to attempt to bring order to the airwaves. ${ }^{130}$ Meanwhile, the post office continued to fight, introducing resolutions in Congress in 1922 and 1923. ${ }^{131}$ House Resolution 14196, for example, sought "to launch a legislative program projecting an ultimate monopoly of electrical means of transmission under postal auspices," but "the measure had little support."132 Hoover, in 1921, had established the Interdepartmental Advisory Committee on Government Broadcasting, including

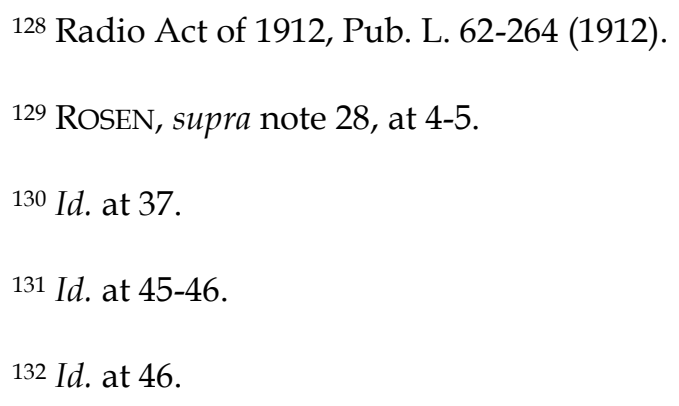


representatives from ten government departments and agencies. He was hoping to gain a mandate for control of radio in the Department of Commerce and to stir up business sentiment against the Navy, which was still reaching for broad control of radio and interfering with business operations. The Navy launched a publicity campaign in 1922 to promote its own cause, and the post office continued to claim "all rights for the transmission of government materials," a position that "effectively isolated the postal service from the navy and the Commerce Department and drastically curtailed any effect it might have on the committee." 133

In January 1923, the interdepartmental committee was renamed the Interdepartmental Radio Advisory Committee, or IRAC, which recommended a regulated private system that would be available to the government in the event of war. ${ }^{134}$ The growing institutionalization of corporate control prompted RCA President James G. Harbord to declare by the end of 1923 that "the 'heresy of government ownership, especially in radio matters,' no longer persisted in the federal bureaucracy." 135 Rosen compares the radio trust broadcasting alliance to

133 Id. at 43 .

${ }^{134}$ Id. at 45. See also Louise M. Benjamin, Regulating the Government's Airwaves: Creation of the Interdepartmental Radio Advisory Committee (IRAC), 51 J. OF BROADCASTING AND ELECTRONIC MEDIA 489 (2007).

135 ROSEN, supra note 28 , at 46. 
railroad pools that would fix prices and divide profits. ${ }^{136}$ They didn't fix prices, but the radio trust essentially colluded with Commerce to protect and preserve the system that would best serve its members interests. Despite the introduction of numerous bills and resolutions in Congress, policymaking was delayed as radio continued to grow and change. ${ }^{137}$

The search for money - how to profit not just off the sale of radio sets but off broadcasting itself - led to ideas and experimentation. Broadcasting was mostly local and the work of amateurs. As AT\&T experimented with new strategies to dominate radio, it shifted attention away from selling transmitters and began constructing commercial facilities designed to transmit paid messages. By 1922, AT\&T received a license to operate its own station, WEAF in New York City, as a facility available for hire; with this, advertising-supported "toll broadcasting" was born. ${ }^{138}$ David Sarnoff, then vice president of RCA, took the next step toward modern forms when he proposed in 1922 "the establishment of a high-quality, nationwide broadcasting organization to be called the 'Public Service Broadcasting Company or National Radio Broadcasting Company or American Radio Broadcasting Company, or some similar name'."139 Sarnoff suggested that the company would include in addition to business men
${ }^{136} I d$. at 48 .
137 Id. at 47-59.
${ }^{138} I d$. at 65.
${ }^{139}$ STARR, supra note 1 , at 336. 
"a few men from outside, prominent in national or civic affairs." 140 Sarnoff even proposed a system of licensing based on private radio sales, not through government, as would happen in Britain with the creation of the British Broadcasting Company around the same time, in 1922.

Meanwhile, Hoover proceeded to grant licenses and organize some broadcasters on specific bandwidths, shifting stations operated by private businesses into the government band of the spectrum even though he had no legal authority to do so. ${ }^{141}$ By 1924, however, "[T]he industry began to establish its own priorities separate and distinct from the Commerce Department and began to support an alternative approach to control under an administrative official." 142 The "industry," at this point, rather than being a cohesive set of commercial interests as the term implies, was still a diverse mix of private broadcasters, ranging from the four radio giants to department stores and newspapers to universities and churches, all competing for limited spectrum and growing weary of Hoover's messy, extralegal approach. Nevertheless, the vision of control of radio by an administrative official would ultimately anticipate the regulatory commissions of the New Deal and the creation of the Federal Radio Commission in 1927.

\footnotetext{
140 Letter to E.W. Rice, 17 June 1922 (quoted in BRIGGS, supra note 16, at 59).

141 STARR, supra note 1 , at 335 .

142 ROSEN, supra note 28 , at 76 .
} 
Broadcasters eventually favored regulation because stations were plagued by interference due to a lack of control. ${ }^{143}$ As Hoover famously commented, "I think this is probably the only industry of the United States that is unanimously in favor of having itself regulated." 144 The dominant commercial players in the industry, of course, wanted to be regulated in a very specific way that would allow them to control the prime real estate in the radio spectrum.

By 1923, with so many groups and individuals competing for the airwaves, Hoover declared the spectrum "closed" and refused to issue any new licenses, which led to a federal appeals court ruling that said Commerce could not deny licenses but could assign frequencies. ${ }^{145}$ Effectively, the Department of Commerce could do little more than register broadcasters and call for selfregulation. Meanwhile, the department worked to craft legislation that would give the department the power it needed to accomplish its goals, and many of these early attempts at legislation invoked the public interest and public service. For example, the commerce department helped to design House bill 11964, “To amend the Radio Act of 1912," which was discussed before the House

${ }^{143}$ Herman S. Hettinger \& William A. Porter, Radio Regulation: A Case Study in Basic Policy Conflicts, 221 AnNAls of THE AM. ACAD. OF POL. \& SOCIAL SCI. 122 (1942).

144 SYDNEY W. HEAD, BROADCASTING IN AMERICA: A SURVEY OF TELEVISION AND RADIO 146 (3rd. ed. 1976).

${ }^{145}$ Hoover v. Intercity Radio Co., Inc., 286 F. 1003 (D.C. Cir. 1923). 
Committee on the Merchant Marine and Fisheries in early $1923 .{ }^{146}$ The bill that would become the 1927 Radio Act was starting to take shape, but at this point the regulatory power was still vested in the Commerce Department rather than an independent commission. The proposed bill gave Commerce power to grant licenses and stated that a license could be revoked "whenever the Secretary of Commerce shall deem such revocation to be in the public interest." 147

Hiram Percy Maxim, representing the American Radio Relay League, an association of amateur operators, was among the witnesses who testified before the committee. ${ }^{148}$ Maxim was not opposed to the idea of vesting licensing power in the Department of Commerce - indeed, nearly everyone accepted that some system of licensing was unavoidable - but Maxim was concerned that the bill made it too easy to push amateurs aside. He contested some language in the proposed bill, fearing that "public service" could provide a rationale for withholding a license from an amateur. Maxim said: "This is not fair or just to the amateurs of the country, and we hope nothing ulterior is intended in this peculiar wording." 149

146 To Amend the Radio Act of 1912: Hearings Before the Committee on the Merchant Marine and Fisheries, 67th Congress, 4th Session (1923).

147 Id. at 2 .

${ }^{148}$ Id. (statement of Hiram Percy Maxim, the American Radio Relay League).

${ }^{149} I d$. at 15 (statement of Hiram Percy Maxim). 
Representative Wallace H. White of Maine responded, using "public interest" interchangeably with "public service." He said he beleived the bill aimed to convey the notion that "the work of the amateur by and large was in the public interest, certainly it was not intended to exclude him."150 In theory, amateur operators would be protected by the public interest, but the vagueness of the term raised questions. White even reflected on the problematic nature of the "public service" language, as possibly offering too much protection in legal terms:

I was a little fearful myself of that language, 'general public service.' Those of us who are lawyers realize that when we speak of a public service corporation we speak of a distinctive class of corporate form. It is not intended to narrow it to a public utility, and I think, perhaps, the language might be improved. ${ }^{151}$

White also wrote that the "whole theory followed in drafting the bill was to get away from specific statutory limitations" on the grounds that "a statutory provision might be obsolete tomorrow." 152 The tendency among regulators was to do as little regulating as possible, and this was for two interconnected reasons.

\footnotetext{
${ }^{150} I d$. at 16 (statement of Wallace H. White).

151 Id. at 17 (statement of Wallace H. White).

${ }^{152} I d$. at 58 (statement of Wallace H. White).
} 
First, policymakers generally had weak understandings of the new technology, especially as it was constantly undergoing change and innovation. Second, they did not want to produce legislation that would be accused of limiting or stifling this innovation.

The proposed legislation reflected this hesitancy. One engineer objected to provisions in the bill "to amend the Radio Act of 1912" that "would give the power to the Secretary of Commerce to exclude, from the requirements of the regulations hereby prescribed or authorized, any radio station and the operators required therein...in which he shall find that such action will facilitate commerce and will not be incompatible with the public interest." 153 This sort of vague provision gave Hoover and the commerce department the power to do what they wanted "in the public interest." The committee's chairman, William S. Greene, replied plainly: "That is what we are going to try to do, of course. We have been at this business for a number of years and we have been trying to liberalize it and not to hamper it." 154

Not surprisingly, the RCA favored the bill, saying in a letter to the committee:

The Radio Corporation [of America] is of the opinion that the purposes of the bill are in the interests of the American public to adequately provide

${ }^{153}$ Id. at 58 (statement of Alfred P. Thom).

${ }^{154} \mathrm{Id}$ 
for regulations which will foster rather than hinder the scientific development of the art, and because it provides what radio needs, a flexible, mobile regulating power. ${ }^{155}$

RCA proposed adding language that would give preference to the dominant broadcasters in matters regarding licensing. The RCA letter, signed by William Brown, RCA's vice president and general attorney, proposed that "the Secretary of Commerce shall take into due consideration the existence and location of existing stations, the property interests, investments, and any equities involved therein, as well as the special adaptability, if any, of the apparatus therein located for use in specific bands of wave lengths." 156 RCA also wanted the bill to protect the property rights of established broadcasters, namely RCA. It proposed language saying, "the Secretary of Commerce may in the public interest or for protection of private property rights prevent the erection and operation of any station hereunder in a location where the operation thereof would materially interfere with the operation of, or property rights in, an existing radio station."157 This idea that the public interest should be associated with efficient station operation unencumbered by interference would become central to the Federal

155 Id. at 59 (letter from William Brown).

${ }^{156} I d$. at 60 (letter from William Brown).

157 Id. at 61 (letter from William Brown). 
Radio Commission's approach to licensing after 1927. RCA was helping to write the script that policymakers would come to rely on.

Even Hoover, when speaking before congressional committees, frequently invoked the public interest regarding regulation, but usually in vague ways or simply to refer to the idea that the public had become interested in radio. ${ }^{158}$ In this sense, the public interest was simply what interested the public. For example, he told the House Committee on the Merchant Marine and Fisheries that the high number of receiving stations meant that "the matter has become one of profound public interest."159

Despite vague or unclear meanings, the public interest language was beginning to appear consistently in any legislation related to radio and in the related congressional hearings. In fact, as early as 1924, House bill 7357, “A Bill to Regulate Radio Communications, and for Other Purposes," which also vested regulatory power in the Department of Commerce, included the "public convenience, interest, or necessity" language that would appear in the 1927 Act. ${ }^{160}$ In his testimony related to this bill, Hoover helped give shape to the public interest language by using it to celebrate the idea that radio had been a success in the United States because it was not subject to over-regulation, but he

${ }^{158} I d$. at 29 (statement of Herbert Hoover).

${ }^{159} \mathrm{Id}$.

160 To Regulate Radio Communication: Hearings Before the Committee on the Merchant Marine and Fisheries, House of Representatives, 68th Congress, 1st Session (1924). 
also noted proposed that radio was not merely a business or meant for private gain. Rather, "[I]t is a public concern impressed with the public trust and to be considered primarily from the standpoint of public interest to the same extent and upon the basis of the same general principles as our other public utilities."161

While Hoover continued to conflate "public interest" and "public utilities," something the lawyers involved were increasingly careful to avoid, he was mainly using the general appeal to the public good to advocate for minimal regulation. At the same time, Hoover also responded to requests by the Navy to lengthen the period for which licenses would be granted. Hoover defended the need for short licensing periods, which would retain power in his hands to make adjustments as technological conditions continued to change. He told the committee that the question of license duration "would go to the heart of the whole question of the public interest in radio" and that "the use of wave lengths in the ether was a public function, a matter of public interest, and should be retained by the Government on behalf of the public. ${ }^{162}$ Again, the appeal to the public good and public interest was a way to justify power and control in his hands.

Hoover put up such a fight for control of radio, it was almost tragic that the regulatory framework he was fighting so hard for would eventually be given by Congress not to him but to an independent commission. Although

\footnotetext{
${ }^{161} \mathrm{Id}$. at 10 (statement of Herbert Hoover).

$162 I d$. at 27 (statement of Herbert Hoover).
} 
government policy in the 1920s, haphazard as it was, clearly favored corporations and the military, by this time, the popular conception of the airwaves and how they would be used was well established: "Whether saving lives at sea or bringing lectures to the farmer, radio was consistently cast as the agent of American democracy and altruism." 163 Susan Douglas suggests that the airwaves needed an altruistic caretaker, and the corporate radio broadcasters worked to position themselves for this role so as to minimize government interference. Douglas wrote:

The badge of legitimacy went to the communications corporations, who burnished its authority by presenting themselves as acting out of benevolent, farsighted paternalism. There were dissenters from this conception of spectrum management, especially among amateurs, educators, and religious groups, and there was some resentment in the 1920s about a potential corporate monopoly of the air. But there was no major break in this ideological frame concerning who was best qualified to serve as warden of the ether. ${ }^{164}$

This corporate paternalism would find parallels in British radio, for the BBC has been described as acting out of the same sort of cultural concern, which will be

163 DOUGLAS, supra note 29 , at 320.

164 Id. at 317 . 
discussed later. What is striking is that even though American paternalism could be seen in the dominant communication corporations and British paternalism came from a government monopoly, both sets of institutions had a similar approach to their social and cultural role in the mid-1920s. Once again, the similarities between the two countries suggest that although causal chains were being laid, they would have to be broken at some point in order to produce divergent outcomes. Douglas ends her story of American radio in 1922, suggesting that the links in the chain of U.S. radio policy were established and unbreakable. But further investigation challenges this notion. Until the passage of the Radio Act of 1927, the commercial structure of radio was hardly a foregone conclusion, and even after 1927, it could hardly be considered stable. Thus, throughout the 1920s, policymakers and a diverse group of public and private interests continued to fight for control of broken chains, as exemplified by Hoover and his series of radio conferences.

\section{HERBERT HOOVER AND THE NATIONAL RADIO CONFERENCES}

The system of broadcast regulation that would emerge from the chaos of the early- and mid-1920s "has been much criticized as a confused jumble of laissez-faire and statist principles." 165 This was the result of efforts by the government and industry to find a solution to a clear instance of market failure,

165 Thomas Streeter, Beyond Freedom of Speech and the Public Interest: The Relevance of Critical Legal Studies to Communications Policy, 40 J. OF COMM. 43, 56 (1990). 
and it was the broad goal Secretary Hoover set out to achieve in the 1920s when he called a series of National Radio Conferences, one each year from 1922 through 1925. More specifically, William Rowland describes the conferences as "the principal federal government efforts reviewing the options for radio regulation in the mid-1920s," and suggests that, "while adopting a public interest gloss," the conferences "were envisioning its application in the context of the well rehearsed cooperation between the government and the private communications industries over the preceding two decades."166 Rowland concludes that the conferences ensured that the government would implement little direct regulation, the idea of public service would mean technological capability, and that license holders would be subject to no specific responsibilities or requirements. ${ }^{167}$

Hoover preferred a system of "regulated individualism," 168 which was on full display during the four National Radio Conferences in the 1920s. In his memoirs, he conveyed the struggle he faced with limited regulatory power and legal authority even as he worked to move the progress of radio forward and control the increasingly chaotic airwaves. This was to be done "in our usual

166 Willard D. Rowland Jr., The Meaning of "The Public Interest" in Communications Policy, Part II: Its Implementation in Early Broadcast Law and Regulation, 2 COMM. L. \& POL'Y 363, 375 (1997). 167 Id. 168 Herbert HoOver, THE MEMOIRs OF Herbert HOOVER: THE CABINET AND THE PRESIDENCY 300-01 (1952). 
fashion of solving problems wherever possible by cooperation rather than by law."169 That the titans of industry desired a monopoly of the airwaves - a property of "enormous financial value"170 - apparently was not lost on Hoover. He was also eager to cooperate with them, in his "usual fashion," devising systems of self-regulation rather than making laws. ${ }^{171}$ He also saw the enormous potential for radio to reach into every American home and provide great benefit to the public, not just as consumers but also as citizens.

The First National Radio Conference convened in Washington in 1922 with more than 1,000 delegates in attendance. The delegates came from a range of government departments, industry, utilities, institutes and universities. In his opening address, Hoover stated:

We are indeed today upon the threshold of a new means of widespread communication of intelligence that has the most profound importance from the point of view of public education and public welfare. The comparative cheapness... of receiving sets...bids fair to make them almost universal in the American home. ${ }^{172}$

\footnotetext{
${ }^{169} \mathrm{Id}$. at 140.

$170 \mathrm{Id}$. at 139.

$171 \mathrm{Id}$. at 140.

$172 \mathrm{Id}$. at 140.
} 
Even in this first conference, Hoover invoked the notion of the public interest, but did so in the context of "central stations" and the "communication of commercial matters," referring to the increasingly dominant private broadcasters who ran stations for the purpose of publicizing their businesses. ${ }^{173}$ His opening statement expressed the central dilemma at the time: Who is in charge of the airwaves? Again he invoked the public interest and, in expressing his views on advertising, made one of his most famous, oft-quoted statements: "[I]t becomes of primary public interest to say who is to do the broadcasting, under what circumstances, and with what type of material. It is inconceivable that we should allow so great a possibility for service to be drowned in advertising chatter."174 Hoover also described to his audience the dilemma of how to finance broadcasting stations, which was a relatively new concern, shifting the focus away from the sale of receiving sets. In two sentences, Hoover described and rejected the general European model: "In certain countries, the government has prohibited the use of receiving instruments except upon payment of a fee, out of which are supported government-sending stations. I believe that such a plan would most seriously limit the development of the art and its social possibilities." 175 The only alternative was a system of regulation required a "policeman" and the establishment of "public right over the ether roads." The
${ }^{173} \mathrm{Id}$.
${ }^{174} \mathrm{Id}$.
${ }^{175} \mathrm{Id}$. at 141. 
"policeman" would be responsible for detecting the "ether hogs that are endangering the traffic." 176 Hoover concluded: "There must be no national regret that we have parted with a great national asset."177

The outcome of this first national conference made clear reference to radio as a public utility to be operated in the public interest. Following the conference, the Commerce Department prepared a report that concluded: “That it is the sense of the conference that radio communication is a public utility and as such should be regulated and controlled by the Federal Government in the public interest."178 The report would also lay out definitions for different types of broadcasting, including government, public, private and toll. Public broadcasting was defined as "signifying broadcasting by public institutions, including State governments political subdivisions thereof, and universities and such others as may be licensed for the purpose of disseminating informational and educational service." Toll broadcasting was defined as "signifying broadcasting where charge is made for the use of the transmitting station." ${ }^{179}$ That these early distinctions were made in 1922 suggests that much remained to be determined about the organization of the airwaves. The report also laid out considerations to

$176 \mathrm{Id}$.

177 Id.

178 Report of the Department of Commerce Conference on Radio Telephony in To Amend the Radio Act of 1912, supra note 146, at 32.

${ }^{179} I d$. at 33 . 
be followed in the granting of licenses and offered preference to stations with high degrees of public interest: "It is recommended that the degree of public interest attaching to a private or toll broadcasting service be considered in determining its priority in the granting of licenses, in the assignment of wave frequencies, and in the assignment of permissible power and operating time, within the general regulations for these classes of service." 180 In this invocation, the idea of "general interest" stations begins to receive priority over propaganda or special interest stations, which would include churches and political groups.

Three more "conferences of the industry"181 were held in Washington, the second in March 1923 and the third in October 1924. In these early years, Hoover "felt we should have more experience before drafting legislation. With the approval of the Congressional committees we carried on until 1924." Congress was not ready to take on such a complicated topic and did not see any great urgency to deal with radio. "One of our troubles in getting legislation was the very success of the voluntary system we had created. Members of the Congressional committees kept saying, 'It is working well, so why bother?' A long period of delay ensued."182

In his opening statement at the third radio conference in 1924, Hoover expressed his continued hope for the future of radio. Even as the broadcasting

\footnotetext{
${ }^{180} I d$. at 36.

${ }^{181}$ HOOVER, supra note 168, at 141.

182 Id. at 142.
} 
industry began to take shape, Hoover again equated the technology to a public utility and expressed concern for its impact on "family life." 183 He concluded by again invoking the public interest. Despite his grand rhetoric, his contextual language at this point does not necessarily suggest an understanding of the concept as a code word for pro-industry regulation as Rowland and others have suggested. He speaks of the position of elites with a self-imposed "high sense of service" in the public interest, and he again invokes parallels with public utilities. $^{184}$

In one sense, he is advocating self-regulation by broadcasters in order to avoid legislation that might have limited their power. But in doing so, he is highlighting a moralistic concern that would have lasting effects. When the Federal Radio Commission was created in 1927, broadcasters were not sure how the new commission would treat the industry, and, for some time, broadcasters considered themselves guests in the home, making efforts to limit the extent to which they exploited their power for commercial aims. ${ }^{185}$ Perhaps this was an early attempt to introduce the idea of social responsibility, in that he suggested

183 Recommendations for Regulation of Radio Adopted by the Third National Radio Conference, Oct. 6-10, 1924, (1924). Hoover's address is printed in Section 1.

$184 \mathrm{Id}$.

185 StARR, supra note 1 , at 341 . See also JAMEs L. BAUghMAN, SAME TIME, SAME STATION:

CREATING AMERICAN TELEVISION, 1948-1961, 25 (2007). 
broadcasters should avoid direct advertising and provide important social and political content.

At the fourth conference in November 1925, Hoover was still advocating and celebrating industry self-regulation, but began to acknowledge the reality of the need for government involvement to balance the interests of the industry. ${ }^{186}$ Among his opening remarks: "I have no hesitation in discussing these questions, because, as I have said, the more the industry can solve for itself the less will be the burden on the Government and the greater will be the freedom of the industry in its own development."187 This is also where Hoover began to make the case for technological supremacy. He laid out the costs of operating a broadcast station and suggested that any limitations on broadcasting would preclude these well-financed stations from being economically successful. It is here that his conception of the public interest begins to shift when he suggests that the public is best served by the "best stations," that is, the stations with the most money and best equipment: "If we impose more division of time than at present, we shall drive the best stations out of action, and the public will be more poorly served. The choice is between public interest and private desire, and we

186 Proceedings of the Fourth National Radio Conference and Recommendations for Regulation of Radio, November 9-11, 1925, in RADIO CONTROL: HEARINGS BEFORE THE COMMITTEE ON INTERSTATE COMMERCE, 69TH CONGRESS, 1ST SESSION, 50-58 (1926).

187 Id. at 53. 
need not hesitate in making a decision."188 Hoover's distinction between the public interest and private desire set up a telling dichotomy. The "public interest" was now being used as part of the market rhetoric that would come to dominate radio regulation. In this context, the public interest reflected a defense of the market, gently regulated by government to make sure the dominant players would all get a share. In other words, the appeal to the public good was now code for letting the dominant broadcasters monopolize the airwaves but only because it was in the interest of the broader community and certainly not because it would serve individual self-interest.

In this context, Hoover would go on to make other now-famous statements. This where he said, for example, "The ether is a public medium, and its use must be for public benefit. The use of a radio channel is justified only if there is public benefit." 189 His public interest rhetoric grew increasingly vague, and perhaps began at this point to take on the pro-industry connotation that would be ascribed to it in the 1927 Radio Act. He said:

I can see no alternative to abandonment of the present system, which gives the broadcasting privilege to everyone who can raise the funds necessary to erect a station, irrespective of his motive, the service he proposes to render, or the number of others already serving his
${ }^{188} I d$. at 55.
${ }^{189} \mathrm{Id}$. at 56. 
community. Moreover, we should not freeze the present users of wave lengths permanently in their favored positions irrespective of their service. That would confer a monopoly of a channel in the air and deprive us of public control over it. It would destroy the public assurance that it will be used for public benefit. There are, indeed, many difficult issues to be solved, but we have to face them just the same.190

The third and fourth radio conferences established a number of committees assigned to different tasks, including allocation of spectrum, advertising, licenses, marine, amateurs, interference and copyright. At the fourth conference, one committee was tasked with developing legislation and, in its remarks, drew, perhaps for the first time, a clear distinction between broadcasting and public utility service, saying that "recognition of the principle of public benefit does not bring the broadcasting stations into the category of recognized public utilities." 191

Add to this defense of the commercial broadcasters the very first resolution appearing in the 1925 conference proceedings. Paul B. Klugh, the executive chairman of the National Association of Broadcasters, proposed that the basis of legislation "should be convenience and necessity, combined with fitness and ability to serve, and due consideration should be given to existing
190 Id. at 57.
191 Id. at 83. 
stations and the services which they have established." 192 Policy scripts were being written by the very industry that was to be regulated. "Fitness and ability to serve" and "due consideration for existing stations" would become central to the meaning of the public interest along with "convenience and necessity" as the impending legislation was crafted.

The central alternative to this approach was reflected in the conference proceedings by Harry J.C. Umberger of Kansas State College, who called for provisions for the many state and public departments and universities that were already making good use of the airwaves. Umberger presented a resolution on behalf of the Department of Agriculture, farmers, and agricultural colleges using radio. He highlighted radio's power to educate and produce public service programs, which would be especially beneficial in rural areas. ${ }^{193}$ If the "public interest" had any meaning at all, surely it was reflected in this proposal, which emphasized service to the public but died in a technical committee. As Rowland concludes, "As the public interest standard was being adopted in the principal forum where private and public interests were being authoritatively welcomed and their results officially sanctioned, the public service notion of broadcasting, a model that would appear to have been central to the public interest, was being systematically ignored."194

\footnotetext{
192 Id. at 59.

${ }^{193} I d$. at 60 .

${ }^{194}$ Rowland, supra note 166, at 373.
} 
Meanwhile, the Tribune Co. v. Oak Leaves Broadcasting Station ${ }^{195}$ case, which relied on a common law property rights solution at the state level, showed a possible alternative to Hoover's preferred method of regulation, and Congress had to act quickly to make sure this alternative did not take root. 196 "That the political marketplace pointedly vetoed a property rights solution that would bypass regulators and legislators while holding entry open into broadcasting was not a reflection of technical incompetence but of self-interested rationality,"197 Thomas Hazlett wrote. American policymakers knew what they were doing when they instituted their preferred solution, a complex powersharing arrangement between government and industry, Hazlett suggested.

In sum, the Fourth National Radio Conference and the mid-1920s generally marked the shift of the meaning of the public interest to give it a clear pro-industry connotation, to divorce broadcasting from any notion of public utility service, and to establish a preference for existing commercial broadcasters who already possessed the technology necessary to provide a national broadcasting service. By delaying legislation in its hesitancy to restrict private business, Congress allowed time for the dominant commercial broadcasters to gain power over the Navy, the post office and amateurs. Thus, the big

195 Gen. No. B-1 36,864 (1926) (Cook Co., Ill., Circ. Ill.).

196 See Thomas W. Hazlett, The Rationality of U.S. Regulation of the Broadcast Spectrum, 33 J.

OF L. \& ECON. 133 (1990).

${ }^{197}$ Id. at 175. 
communications corporations were poised to come out on top with the creation of the Federal Radio Commission in 1927.

The mid-1920s had seen increasing chaos as amateurs and non-corporate broadcasters including universities, religious groups and labor organizations competed for the airwaves with the emerging commercial stations operated by private businesses. The messy situation finally came to a head when the government sued the Zenith Corporation for violating spectrum-use rules in its broadcasts and a district court found in 1926 that Secretary Hoover was in fact powerless to regulate broadcasting under the 1912 Radio Act. ${ }^{198}$ This opinion was confirmed by the attorney general, who wrote, "[T]he present legislation is inadequate to cover the art of broadcasting, which has been almost entirely developed since the passage of the 1912 Act. If the present situation requires control, I can only suggest that it be sought in new legislation, carefully adapted to meet the needs of both the present and the future." 199 In this context, Congress would finally decide to act.

THE BIRTH OF THE BRITISH BROADCASTING COMPANY

198 United States v. Zenith Radio Corp., 12 F. 2d 614 (N.D. Ill. 1926).

19935 Op. Att'y Gen. 126 (1926) (reprinted in DOCUMENTS OF AMERICAN BROADCASTING 2731 (Frank J. Kahn ed., 1984). 
At the start of the 1920s, Britain had not yet decided what path its broadcasting system would take. ${ }^{200}$ As in the United States, Britain had instituted a ban on amateur radio during the first world war, and as in the United States, the ban was lifted in 1919. As amateur operators resumed their work, the realization that broadcasting regular entertainment over the airwaves could stimulate the sale of wireless receivers came to British radio manufacturers, just as it had in the U.S. But the U.S. radio companies had become more technologically advanced than British Marconi and the other British manufacturers, possibly because the U.S. had lost less time to the war. "America's lead time was envied in Britain and quickened the pace of development in Britain, but the use made by American broadcasters of their lead served as a warning rather than an example," ${ }^{201}$ Asa Briggs wrote. Perhaps the British system was slow to catch up, but this may have been an advantage in that it gave regulators more time to observe what was happening in the United States and to think about how to approach the new technology.

Still, commercial pressures did exist in Britain, and the broadcasting boom in the United States didn't help. After the war, the national security argument for government control of broadcasting gave way to pressure from wireless manufacturers and amateur radio operators to authorize a regular broadcasting

200 This history is based on BRIGGS, supra note 16, at 36-58; CRISELL, supra note 110, at 1720.

201 BRIGGS, supra note 16, at 59-60. 
service. ${ }^{202}$ As a result, the post office allowed the Marconi Company to broadcast from a sole transmitter at Writtle near Chelmsford but warned them not to encroach on military transmissions. The Post Office eventually allowed a few other stations to broadcast but never granted any official, permanent licenses to operate due to the unresolved question of how to deal with the technological problem of spectrum scarcity, the limited availability of frequencies on which to broadcast. The Marconi Company began experimental broadcasting in February 1920, but did not begin a regular broadcasting service until February 14, 1922, a full year-and-a-half after the first KDKA broadcast in the United States Marconi's London station, 2LO, began broadcasting - under major restrictions - on May 11, 1922. Other radio manufacturers soon began to show interest. At that point, the post office, "[A]nxious to avoid the chaos that had arisen from unrestrained broadcasting in the United States and unwilling to have to arbitrate between rival interests in the British radio industry," negotiated the formation of a cartel of the radio manufacturers. ${ }^{203}$ In the spring of 1922, discussions between the various radio manufacturers and the post office led to the formation of the British Broadcasting Company. (It would remain a "company" until it became the British Broadcasting Corporation in 1927.) The Company began broadcasting on November 14, 1922, but did not receive an official license from the post office until January 18, 1923.

\footnotetext{
202 See CRISELL, supra note 110, at 14-20.

203 SCANNELL \& CARDIFF, supra note 23, at 5.
} 
Before this could happen, though, a few decisions had to be made. F.J. Brown, an assistant secretary at the post office, had been visiting the United States and attended Hoover's First National Radio Conference in early 1922. The lessons he learned about frequency chaos were apparent in a report made by the postmaster general in Parliament in 1922:

...it would be impossible to have a large number of firms broadcasting. That is physically impossible. It would result in a sort of chaos, only in a much aggravated form than that which has arisen in the United States of America, and which has compelled the United States, or the Department over which Mr. Hoover presides, and who is responsible for broadcasting, to do what we are now doing at the beginning, that is, proceed to lay down very drastic regulations, indeed, for the control of wireless broadcasting. 204

Thus, when the post office received twenty new applications for permission to broadcast in the spring of 1922, the reply was always "the ether is already full." 205 In the sense of closing the ether, Britain's post office was a full year ahead of Hoover's commerce department. Instead of the indiscriminate granting of licenses, the British Postmaster General F.G. Kellaway told Parliament that he

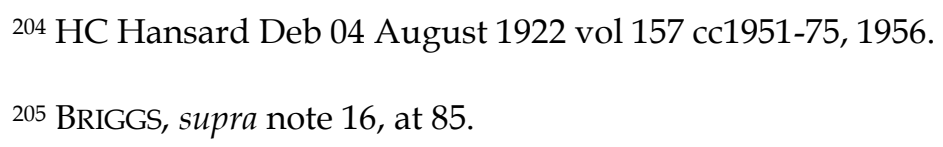


would "ask all those who apply - the various firms who have applied - to come together at the Post Office and co-operate so that an efficient service may be rendered and that there may be no danger of monopoly and that each service shall not be interfering with the efficient working of the other." 206 This early view expressed a concern for striking a balance between efficiency of service and maintaining equal barriers to entry.

That same spring, the Wireless Sub-Committee of the Imperial Communications Committee began designing the strict set of controls that would govern operations of the British Broadcasting Company. By 1922, the syndicate of six private British companies had an effective monopoly over the airwaves, although "it was at first denied that the British Broadcasting Company was a monopoly, because entry into the company was allowed to any genuine British manufacturer in the radio industry." 207 Complaints about monopoly came mostly from the popular press, which thought radio would harm newspaper circulation.

The Wireless Sub-Committee of the Imperial Communications Committee would eventually come up with a set of rules for broadcasting. The subcommittee set limits on the days and times that broadcasters could use the airwaves, it placed technical limitations on power and manner of transmissions, and it ruled that facilities "should be given to bona fide radio manufacturing companies to broadcast news and educational matter," which then and later

\footnotetext{
${ }^{206}$ Hansard, vol. 153, col. 1600, 4 May 1922. (quoted in BRIGGS, supra note 16, at 100).

207 SCANNELL \& CARDIFF, supra note 23, at 6.
} 
prevented applicants such as newspapers and retail stores from entering the industry. ${ }^{208}$ Furthermore, agreements between the post office and the manufacturers dictated that the original BBC would be funded by three sources: original stock, royalties on wireless sets sold by manufacturers, and receiving licenses collected by the post office from the public. These severe limitations on such important technical and financial questions provided a sharp contrast to the American approach, just as they were meant to do in light of the chaos in the United States. As Briggs noted, “American broadcasting had blundered into chaos: British broadcasting was to be forced into a strait-jacket."209 Unresolved matters remained related to questions of control of content. Postmaster General Kellaway had said that "there will be certain regulations in regard to the character and classes of news which these agencies will be allowed to transmit, but on that head I have not yet come to a final decision." 210 Kellaway avoided questions about censorship of content, but this early statement about "character and class" suggested the possibility of content control through some means and anticipated the leadership of John Reith. ${ }^{211}$ At the same time, at least part of Kellaway's concern about "content" had to do with the calls from the British press that broadcasters should be restricted from producing original news

208 BRIGGS, supra note 16 , at 97.

209 Id. at 98 .

210 Hansard, vol. 153, col. 1600, 4 May 1922 (quoted in BRIGGS, supra note 16, at 100).

211 Id. 
reports so as to minimize competition with the newspaper industry. Kellaway also had to contend with members of Parliament who attacked the emerging plan for broadcasting as monopolistic and in violation of free trade. He responded by saying that the post office's approach actually promoted competition in broadcasting and would serve national business interests by restricting access by foreign radio manufacturers to Britain's radio market. ${ }^{212}$ Ultimately, Kellaway and the post office took their time in addressing these matters. "It was the concern of the post office with matters like these-matters which involved its conception of the 'public interest' - which held back progress in the late summer and autumn of 1922,"213 Briggs wrote. Kellaway wanted to ensure that the broadcasting service to emerge from the Post Office's long deliberations would be one he would not have to defend to angry members of Parliament, the press, the broadcasters, the radio manufacturers, or the public. ${ }^{214}$ He knew, whatever the outcome, he would be held responsible.

One month after the British Broadcasting Company began regular broadcasts, it hired a general manager named John Reith, a 34-year-old Scottish engineer who knew nothing about broadcasting but came highly recommended. ${ }^{215}$ Reith, from the start, had concluded that broadcasting was a

\footnotetext{
212 BRIGGS, supra note 16, at 120-123.

${ }^{213} \mathrm{Id}$. at 123.

214 See BRIGGS, supra note 16, 120-123.

215 BRIGGS, supra note 16, at 135.
} 
"precious national resource - too precious to be used merely to deliver audiences to advertisers or even to wireless manufacturers." 216 Reith wanted the BBC to operate as a monopoly, remain institutionally independent, be funded by a license fee, be accessible to all, and maintain high standards. ${ }^{217}$ These characteristics were not simply the original thinking of Reith; they had organizational precedents in Britain in the context of the rise of the public corporation in the early 1900s. ${ }^{218}$ The forestry, gas, water and electricity industries had been organized as public corporations and designed to combine the best of civil and commercial values. ${ }^{219}$ Thus, the BBC already possessed some of these qualities before Reith's arrival. The structures already in place, to some extent, dictated that the technology would eventually be organized as a public resource. The early shareholder rates of return were modest, and the companies were never driven primarily by profit. Perhaps most significant is the fact that the British government approved the licensing fee from the beginning to cushion the $\mathrm{BBC}$ from having to rely too heavily on profit.

Considering all this, to say that the BBC began as a private company is somewhat misleading. The company was so heavily regulated by government that it was basically a public institution from the start, and much of its funding

\footnotetext{
${ }^{216}$ CRISELL, supra note 110, at 18.

217 Id. at 19.

${ }^{218}$ Id. See also CURRAN \& SEATON, supra note 50, at 105.

${ }^{219}$ CURRAN \& SEATON, supra note 50, at 138-39.
} 
came from royalties and licenses collected by government on the company's behalf. All of this had happened somewhat haphazardly, largely in reaction to the perceived chaos in the United States. But as Paddy Scannell and David Cardiff and others argue, the initial goal was to create a market for the sale of radio receivers; the notion of broadcasting as a public service came later. ${ }^{220}$ Notably, however, the public service concept did come, and it came even though there was no real need for it. The public service approach may have actually been detrimental to the demand for radio sets; perhaps an American-style, commercial, entertainment-oriented approach to broadcasting would have made radio in Britain all the more popular. But John Reith wouldn't have it. Reith's approach to public service broadcasting in 1924 had been informed and emboldened the year before by the work and report of The Broadcasting Committee, better known as the Sykes Committee, on which Reith served as a member.

John Reith AND the Theory of Public Service

It seems that Reith had a sense of the grandeur of what was about to happen. In an entry in his diary dated December 28, 1922, just a month-and-ahalf after his hiring, Reith wishes for his mother to live to see him made a knight. ${ }^{221}$ He continues:

220 SCANNELL \& CARDIFF, supra note 23 , at 5.

221 CHARLES STUART ED., THE REITH DiARIES 129 (1975). 
I feel if this job succeeds and I am given grace to succeed in it, I might not be so far off this. I do want a title for dear Mother's sake and Muriel's [his wife] and other similar reasons. May I never forget dear Mother's prayer. I must take Christ with me from the very beginning and all through this difficult work. I cannot succeed otherwise. “Without me ye can do nothing." I can do all things through Christ.222

In many ways, this sounds downright delusional. But he was not far off. This also makes clear how Reith would carry his strong religious background with him in his work at the BBC. As Briggs notes, "Reith's whole conception of moral standards derived from Christian principles." 223 But these principles meant more to Reith than mere moralizing over the airwaves. They would inform his view of the public, of economics and of technology.

As Briggs points out, Reith never refers to "mass media" or "mass communication" in any of his writings. Instead he emphasizes the "public" or the "publics" as part of "the great audience," not to be analyzed for tastes and preferences to be pandered to, but as humans in need of cultural enrichment and fulfillment. Briggs writes:

$222 I d$.

${ }^{223}$ BRIGGS, supra note 16, at 272. 
The "publics" are treated with respect not as nameless aggregates with statistically measurable preferences, "targets" for the programme sponsor, but as living audiences capable of growth and development. In other words, Reith's theory of public service began with a conception of the public. Without such a conception the conception of public service itself becomes bleak and arid.224

It is easy to imagine how this sort of approach would earn Reith charges of elitism and socialism, which he did not shy from. In his book Broadcast Over Britain, written hastily in 1924, Reith countered these charges with simple appeals to reason: "To disregard the spread of knowledge, with the consequent enlargement of opinion, and to be unable to supplement it with reasoned arguments, or to supply satisfactory answers to legitimate and intelligent questions, is not only dangerous but stupid." 225 Reith's book, one of the most important documents in the history of broadcasting, expresses a bold vision for public service broadcasting and did much to influence the future of the BBC. It is important to note that Reith's approach to public service broadcasting in 1924 had been informed and emboldened the year before by the work and report of the Broadcasting Committee, better known as the Sykes Committee, on which Reith served as a member.

\footnotetext{
${ }^{224} I d$. at 239.

${ }^{225}$ JOHN C.W. REITH, BROADCAST OVER BRITAIN 19 (1924).
} 
The Sykes Committee, named for its chairman Sir Frederick Sykes, was appointed by the postmaster general April 24, 1923, to consider "broadcasting in all its aspects" as well as "the action which should be taken upon the determination of the existing licence of the Broadcasting Company" and the "restrictions which may need to be placed upon its user or development." 226 The committee recognized the future importance of the new technology and began its work under the assumption that "the control of such a potential power over public opinion and the life of the nation ought to remain with the State, and that the operation of so important a national service ought not to be allowed to become an unrestricted commercial monopoly." 227 To this end, the committee declared the airwaves to be "regarded as a valuable form of public property; and the right to use them for any purpose should only be given after full and careful consideration." 228 The committee also recognized from the start that the outcome it recommended was likely to have a lasting effect, opening and closing certain alternative paths. The committee declared that any wavelengths "assigned to any particular interest should be subject to the safeguards necessary to protect the public interest in the future. Should readjustments become necessary after definite allocations of the national property, they may be found both difficult and

226 SYKes COMMitTeE, RePORT Of THE BROAdCASTING COMMITTEE (Cd. 1951) 5 (1923).

227 Id. at 6.

${ }^{228} \mathrm{Id}$. 
costly." 229 Indeed, exit costs are central to the concept of path dependence and explain why it is hard to stray from chosen paths. These costs can be material or nonmaterial, as is the case with the inefficient QWERTY keyboard still used. In the case of broadcasting, substantial costs, both material and nonmaterial, would be involved in attempts to alter future paths in both Britain and the United States.

Due to the provisional nature of the agreements governing British broadcasting, the Sykes Committee was asked to respond to the original license granted to the British Broadcasting Company in January 1923.230 The license outlined all the ways in which the Company was already operating like a public monopoly. ${ }^{231}$ Manufacturers had to pay to join and be approved by the postmaster general. The post office issued broadcast receiving licenses and sets were marked “BBC - Type approved by Postmaster General." The post office paid the Company half of the licensing fees received. And receiving sets had to be British-made and carry a tax payment to the company as approved by the postmaster general. Furthermore, no "advertising or paid matter" was to be broadcast, and "only such news as is obtained from news agencies approved by

${ }^{229} \mathrm{Id}$.

230 Wireless Broadcasting Licence (Cmd. 1822) (1923).

231 The "outline of the existing scheme" is summarized in Sykes Committee, supra note 226, at 8-9. 
the Postmaster General" was allowed. The Company also was "not to pay dividends at a higher rate than 7.5 per cent per annum." 232

It is fine to say that technical restrictions on wavelengths and policies regarding Company organization were due to the limited nature of the airwaves, or at least the current understanding of the airwaves at the time. And the restrictions on types of radio sets to be used and the requirement of receiving licenses were certainly meant to help national industry and increase revenue for the post office. But the restrictions on content - certain types of news and advertising - reflect different interests. The limits on news broadcasts and advertising were meant to protect the publishing industry, although these restrictions on news would loosen throughout the decade, partly due to Reith's insistence. As Scannell and Cardiff note: "The restrictive attitude of the Post Office which, at the time, had forbidden the BBC to deal with any matters of public controversy, was severely restricting the development of this side of broadcasting, and Reith sharply criticized the shackles imposed on radio's treatment of news and politics."233

The restrictions on advertising, however, reflect perhaps the biggest difference between the British and American approaches to broadcasting. Beyond protecting newspapers, the Sykes Committee feared that advertising

\footnotetext{
232 Sykes Committee, supra note 226, at 9.

233 SCANNELL \& CARDIFF, supra note 23, at 8.
} 
would lead to lower standards and make the service unpopular. ${ }^{234}$ The Committee reports that it would be permissible to accept the "gift" of a concert and broadcast the name of the donor, or to name the publisher and price of a song to be played. It also ruled on the "Broadcasting of Commercial Information," saying "this would be permitted if extra revenue is needed, but limited to a block of five minutes per hour, for example, and under suitable safeguards." 235 These sorts of declarations, coming from the mainstream policymakers, were unlike what was happening in the United States in 1923. Although Hoover had claimed to be opposed to advertising - it was “inconceivable that we should allow so great a possibility for service...to be drowned in advertising chatter," He declared at the first radio conference in $1922^{236}$ - this grand rhetoric never worked itself into any specific recommendations or requirements as it would in Britain.

One reason for this was that radio in the United States had developed so quickly and with so little regulatory authority that there had been no time to implement an organized, universal approach to financing broadcasting. Britain's slightly late arrival to the radio craze gave it a great advantage in this regard. The aims of the original British approach to radio had been "to secure the early establishment of an efficient and attractive broadcasting service without cost to

\footnotetext{
234 Sykes Committee, supra note 226, at 19.

${ }^{235} \mathrm{Id}$. at $19-20$.

${ }^{236}$ HOOVER, supra note 168 , at 140.
} 
the taxpayer and without the establishment of any manufacturing monopoly," 237 and the outcome in 1923 was thought by many to have actually achieved this goal. The Company was a consortium of manufacturers rather than a monopoly of one, and the cost for broadcasting was paid by the end user in the form of the radio license. Barring the early introduction of such a licensing scheme, it would be difficult to implement such an approach later. The committee's approach to the funding model, while resting on "the educative value of broadcasting," 238 precluded a tax on the general population. Instead, the committee approved of the licensing fee approach and recommended that "the Government should not aim at making a profit on the control of the service or the licensing of wireless sets." 239

It is worth noting that some Britons evaded the licensing fee by building their own sets. The promise had been made in the House of Commons in July 1922 that "amateurs who construct their own receiving sets...will be allowed to use them." It was

[T] he view then taken by the Post Office being that if an applicant were sufficiently skilled to make his own apparatus he would have sufficient knowledge to make proper use of an experimental license, which is free of

237 Sykes Committee, supra note 226, at 10.

${ }^{238}$ Id. at 17.

${ }^{239} \mathrm{Id}$. 
the restriction inserted in the broadcasting license as to the type of apparatus. ${ }^{240}$

Based on this early promise, radio parts, both domestic and foreign-made, began to appear on the market, undermining the official Company sets, because homemade sets were cheaper. Ultimately, “[T]he Post Office agreed in January, 1923, to issue experimental licenses only to persons with unquestionable qualifications, the applications from other persons being held over for further consideration." 241 They discussed the possibility of a "constructor's" license for those who wanted to use homemade sets, but this never became a reality, as the post office and the Company could never come to an agreement on the conditions under which such a license would be issued.

This problem was indicative of one of the central objections to the scheme thus far. The Sykes Committee noted that these objections centered on the notions that it was wrong to control the manufacture and importation of wireless apparatus, and that firms had to join the Company in order to manufacture and sell apparatus. It was wrong that "the Company is practically controlled by a few large firms, who, it is suggested, are placed in a position of advantage over smaller trade rivals," and "certain conditions of the agreement which members of the British Broadcasting Company have to sign are of an oppressive character

\footnotetext{
${ }^{240} I d$. at 9.

${ }^{241} I d$. at 10 .
} 
or give the Company powers which might be used harshly." 242 Despite these objections, the Sykes Committee did not hesitate to recommend "that permission to transmit, and the matter to be transmitted, should be subject to public authority." 243 That the Committee would include the "matter to be transmitted" was an early indication that someone would be in charge of the content of broadcasting. The Committee proposed a broadcasting board to work out the details in conjunction with the post office.

As to the question of state operation, the Sykes Committee recognized that "once the principle of public control is established, it is evident that considerable latitude is possible in deciding by whom broadcasting should be operated."244 The committee recognized that the actual operation of so important a national service "should be in the hands of the Government rather than in private hands." 245 On the other hand, the committee also recognized that government would not be suited to handle entertainment programming and that it would be subject to criticism regarding political power and influence. The governmentcontrolled operation "would be constantly open to suspicion that it was using its unique opportunities to advance the interests of the political party in power; and, in the endeavour to avoid anything in the slightest degree controversial, it would

242 Id. at 11.

243 Id. at 12.

244 Id. at 13.

245 Id. 
probably succeed in making its service intolerably dull." 246 Ultimately the committee's recommendation favored state control but noted that "care should be taken to interfere as little as possible with the broadcast programming." 247

The committee's final recommendation was the creation of the Broadcasting Board to assist the postmaster general, noting that "the broadcasting service should not be operated by a Government Department, but that those entrusted with the service should work under Governmental licence." 248 This recommendation was in keeping with the scheme established under the original Company license but suggested and anticipated the transformation of the Company into a public corporation. It is significant that although these recommendations in the interest of public service originated with the British government, they were realized by the broadcasters themselves. As Scannell and Cardiff note, this

[D]efinition of broadcasting as a public utility to be developed as a national service in the public interest came from the state. The interpretation of that definition, the effort to realize its meaning in the development of a programme service guided by considerations of national

\footnotetext{
${ }^{246} I d$. at 14 .

$247 \mathrm{Id}$.

$248 \mathrm{Id}$. at 34-35.
} 
service and the public interest, came from the broadcasters and above all from John Reith. ${ }^{249}$

Reith's vision was informed by his desire to use the new technology to serve the public by encouraging widespread access to knowledge and culture.

Reith was eager to promote his cause and to defend his approach in the face of criticisms of the elitist monopoly. "I think it will be admitted by all that to have exploited so great a scientific invention for the purpose and pursuit of entertainment alone would have been a prostitution of its powers and an insult to the character and intelligence of the people," 250 he wrote. He also specifically characterized the Company as a utility and emphasized its non-profit nature: "The Company operates as a public utility service, and it is of great importance that this should be definitely recognized. In other words, the Company is not out to make money for the sake of making money; by its constitution it is debarred from doing so." 251 Furthermore, Reith argued that a broadcasting service that operated in this manner would actually benefit British industry rather than detract from it. "In this business, the interests of the public and the interests of the trade happen to be identical, even though this may not be apparent at first sight," he wrote. "The greater the extent to which, as a public service, the

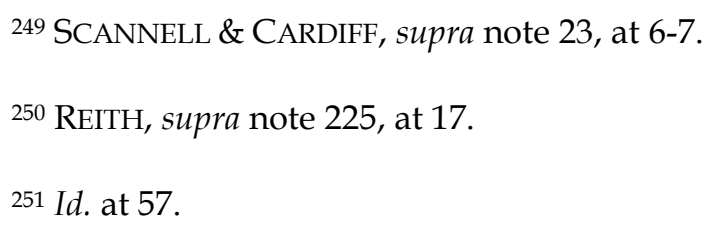


Company is able to give satisfaction, the greater the benefit to the new British industry." $252 \mathrm{He}$ also dismissed monopoly concerns by noting that "unity of control" was essential "in a concern where expansion is so rapid and the problems so unique." 253 Reith had always preferred the term "unified control" over "monopoly," which he avoided using. Finally, he compared the British system to the American approach, pointing out that the delay in initiating a broadcasting service in Britain served the country well:

In America broadcasting had been initiated more than a year earlier than in this country; with characteristic energy it had been developed wholesale, largely on a commercial basis, and without any method of control whatsoever. There is no co-ordination, no standard, no guiding policy; advertising, direct or indirect, is usually the sole means of revenue. I gather from many American visitors that they consider that the delay which took place before a service was begun in this country, is more than justified by the progress subsequently made. There is scarcely a civilized country of which representatives have not visited us, usually staying for a period, to absorb something of the procedure and methods of operation.

\footnotetext{
${ }^{252} \mathrm{Id}$.
}

${ }^{253} \mathrm{Id}$. at 70 . 
We are always glad to see them. We make no copyright of our experience, however valuable or unique it may be. 254

By the mid-1920s, Reith and the Company were facing less and less resistance as their approach became more and more accepted throughout Britain. For example, an article in The Times was indicative of the realization that the monopoly approach was preferable to American-style competition.

But in this case we have to consider the alternative to monopoly: it would be, almost certainly, confusion, and quite certainly the debasement of an influence far too permeating to be allowed to be vulgarized....It is now a monopoly, but in generous and humane hands the interest of the majority will probably be in its continuing to be a monopoly. .255

As this consensus grew, the transformation of the BBC from Company to Corporation came closer.

\section{THE CRAWFORD COMMitTEE AND THE TRANSFORMATION OF THE BBC}

Radio in Britain was exploding throughout the 1920s and 1930s. In 1923, the post office issued 80,000 receiving licenses. In 1924, it issued one million. And

${ }^{254} I d$. at 81.

255 THE TIMES, Nov. 15, 1924 (quoted in BRIGGS, supra note 16, at 329). 
by 1939, the number was nine million. ${ }^{256}$ Between 1922 and 1924, nine main stations and ten relay stations had been set up in England, Wales, Scotland and Northern Ireland, and they reached nearly $80 \%$ of the population..$^{257}$ Despite this growth, in the mid-1920s, there was no discussion in Parliament of major matters of broadcast policy until late 1926. Rather, Parliament was concerned with setting up the Empire Wireless Communications Network. ${ }^{258}$ One notable policy change was that the embargo against foreign radio receivers was dropped as of December 31, 1924, because the post office had switched to a single form of receiving license for all types of equipment. As early as 1923, however, the postmaster general had already appointed another committee to review the $B B C$ 's finances.

As early as 1923, the postmaster general had already appointed another committee to review the BBC's finances. This second broadcasting committee, known as the "Crawford Committee" after the chairman, met in 1925 and made its report in 1926. The goal was "to advise as to the proper scope of the Broadcasting service and as to the management, control and finance thereof" after the expiration of the existing Company license, which was set to end on

\footnotetext{
256 See CRISELL, supra note 110, at 22-24.

257 See SCANNELL \& CARDIFF, supra note 23, at 15.

${ }^{258} I d$. at 23.
} 
December 31, 1926. ${ }^{259}$ Much like the Sykes Committee, the Crawford Committee recognized the public service role of broadcasting and rejected advertising on the grounds that it would lead to lower standards. Monopoly was advocated as an efficient way to provide successful service and a way to ensure quality programming. As Valeria Camporesi notes, "Broadcasting had come to be viewed as too delicate a matter to be left to the market."260 Not only did the committee believe that "competition for listeners would force down program standards," as Paulu notes, but it was operating in a context where government monopoly "was strongly supported by the articulate public of that day." 261

Ultimately, there would be no major opposition to the change to public corporation, which was meant to solidify the monopoly and protect it from both political and commercial influence by changing it from a regulated private entity to a government-owned operation protected by royal charter. The post office was supportive of the change, as was public opinion. ${ }^{262}$ The committee recommended the single licensing fee of 10 shillings, and $75 \%$ was to go to the BBC. ${ }^{263}$ It also

259 CRAWFORd COMMITTEE, RePORT OF THE BROAdCASting COMMITTEE, 1925 (Cmd. 2599) 2 (1926).

260 VALERIA CAMPORESI, MASS CULTURE AND NATIONAL TRADITIONS: THE BBC AND AMERICAN BROADCASTING, 1922-1954 23 (2000).

261 PAULU, supra note 45, at 14.

262 See SCANNELL \& CARDIFF, supra note 23 , at 8-9.

263 See Crisell, supra note 110, at 22. 
recommended that wireless receiver royalty payments to radio manufacturers should stop. The licensing system remained problematic, however, as the post office didn't want to collect fees on behalf of a private company. Reith maintained that broadcasting was a public service, and that the public should pay for it, not advertisers. ${ }^{264}$ This led Reith and the Crawford Committee to advocate for making the BBC a public corporation. The British government was sympathetic, as this institutional model was now popular and widely accepted. ${ }^{265}$

Like the Sykes Committee, the Crawford Committee reported that it was "deeply conscious of the magnitude of the issues involved - not merely as regards their scientific or mechanical aspects, but still more in relation to their ultimate impact on the education and temperament of the country."266 As before, the Crawford Committee maintained that the "United States system of free and uncontrolled transmission and reception, is unsuited to this country, and that Broadcasting must accordingly remain a monopoly - in other words that the whole organization must be controlled by a single authority." 267 The committee recommended against the continuation of the current Company license and instead advocated for a public corporation form of organization. A central reason

264 Id. at 24.

$265 I d$.

266 Crawford Committee, supra note 259, at 4.

267 Id. at 5. 
for this was to insulate the operations of the broadcasting service from politics and to provide leeway in selecting content. "Such an authority would enjoy a freedom and flexibility which a Minister of State himself could scarcely exercise in arranging for performers and programmes, and in studying the variable demands of public taste and necessity,"268 it reported.

Furthermore, the committee recommended that the commissioners of the new corporation "should be persons of judgment and independence, free of commitments, and that they will inspire confidence by having no other interests to promote than those of the public service. We hope they will be men and women of business acumen and experienced in affairs." 269 The committee was clear that it was authorizing a monopoly "vested by Statute in the whole Community," and said that in this context, "the State safeguards the listener against exploitation; takes steps to maintain the efficiency of the service, and also exercises its regulative powers without which broadcasting would be thrown into chaos." 270 Looking to the future, the committee noted that they could not predict the future of broadcasting and envisioned two different possible outcomes. "On the one hand it is conceivable that Broadcasting might have to become a department of State like the telephone service: on the other it is possible that its character as a monopoly might have to disappear, and that the
$268 \mathrm{Id}$.
${ }^{269} \mathrm{Id}$. at 7.
${ }^{270} I d$. at 8 . 
rights of transmitting should be distributed." 271 In the latter possibility, the Crawford Committee anticipated correctly that competition would eventually be introduced to British broadcasting.

Although Reith was not a member of the Crawford Committee, he and the committee shared the same vision for broadcasting, and the committee stressed the educative value of radio. The committee called for the maintenance of high standards and praised the BBC for having "held the balance between conflicting tastes with discretion." The committee recommended that listeners be afforded "latitude" in available content. "He must not be pressed to assimilate too much of what he calls 'highbrow' broadcast, and the Commissioners would not be wise in transmitting more educational matter than licensees are prepared to accept. At the same time every effort must be made to raise the standard of style and performance." 272 In many ways, Reith and the BBC would inform if not create the normative roles not just of broadcasting but modern journalism in general, especially as the $\mathrm{BBC}$ began to broadcast more news and public affairs programs in the late 1920s and 1930s. It is certainly remarkable that Reith would eventually institute at the BBC the types of goals and norms that would be celebrated and codified in the decades to come, for example, in the Pilkington Report and Hutchins Commission. It is worth noting that these norms were largely possible because of the unique structure of the organization, which "depended on the

\footnotetext{
${ }^{271} I d$. at 9.

272 Id. at 12 .
} 
rejection of both market forces and politics in favour of efficiency and planned growth by experts." 273

A problem arose, however, with the 1926 general strike in Britain, during which questions arose about how a public broadcasting system would cover the actions of government. ${ }^{274}$ Some in government, including Winston Churchill, had growing concerned about seditious speech and wanted to commandeer broadcasting altogether but were prevented from doing so. As Brian McNair wrote:

During the 1926 General Strike Winston Churchill, then the Home Secretary, wanted to take direct control of the BBC and use it openly as a propaganda tool. He was overruled in government by those who argued that this would undermine the very thing which made the $\mathrm{BBC}$ a valuable ideological weapon-its perceived independence. ${ }^{275}$

This does not mean the BBC went without being criticized, for many believed that the government had exercised some control over coverage of the strike. ${ }^{276}$

273 CURRAN \& SEATON, supra note 50, at 139.

274 See CRISELL, supra note 110, at 24-25.

275 BRIAN MCNAIR, NEWS AND JOURNALISM IN THE UK 57 (3rd. ed. 1999) (emphasis in original).

276 CRISELL, supra note 110, at 25. 
"Even if it proved possible - thanks largely to the licence fee - to resist the identification of the BBC with a department of State," Krishan Kuman wrote, "there persisted the vexing association of 'public service' with service to the State seen as the embodiment of the national or public interest." 277

The early BBC tended to avoid politics, especially in light of restrictions on news content that were only gradually lifted. In fact, this may have been one of the reasons the organization was successful. This was partly due to Reith's own predisposition against politics in favor of other fare. As Kuman notes:

The early BBC dealt with the problem by avoiding it. Reith despised politics and politicians, and sought to maintain the BBC's independence by ignoring the contentious and, to him, sterile realm of political debate....This left the BBC free to get on with what Reith considered the important talks: building it up as a cultural church. Politics did not matter: philosophy, religion, music, poetry and drama - laced with 'light entertainment' as ground-bait - did. 278

The BBC was widely praised for its attention to these sorts of cultural affairs. At the same time, the notion of the early BBC as an immediately hailed cultural

277 Krishan Kuman, Public Service Broadcasting and the Public Interest, in THE BBC AND Public Service BroadCAsting 46 (Colin MacCabe \& Olivia Stewart eds., 1986).

${ }^{278}$ Id. at 47. 
institution speaking for the masses has been challenged. "Its relative newness, its conception of its role as the guardian of high culture and morality, its selfdenying ordinances against dealing with 'controversial' matters, all militated against a true involvement with the deeper and more varied levels of the society," 279 Kuman wrote.

But others point out that the BBC's service of high culture was not a new idea in Britain, and this is the reason the broadcasting service was successful. Reith and company were really just riding on the coattails of the success of the Victorian middle class, which brought the ideal of service to the forefront in late nineteenth century Britain, as Raymond Williams first suggested. Referencing Williams, Scannell and Cardiff write: "The Victorian reforming ideal of service was animated by a sense of moral purpose and of social duty on behalf of the community, aimed particularly at those most in need of reforming - the lower classes." 280 Indeed, the motivation behind the ideal of service wasn't always so altruistic, and this is where the $\mathrm{BBC}$ earned its reputation as a hegemonic cultural dictator. Referencing Culture and Anarchy by Matthew Arnold, Scannell and Cardiff explain the nineteenth-century political motivations for "civilizing" the masses and "incorporating the working classes within the existing social and political order, and thus preventing the threat of revolt from below." 281 Whether

${ }^{279} I d$. at 50 .

280 SCANNELL \& CARDIFF, supra note 23 , at 9.

${ }^{281} I d$. 
oppressing the masses through cultural hegemony or destroying culture though standardization and democratization, the $\mathrm{BBC}$ was always doing something wrong in eyes of many cultural critics. But somehow, it still survived, and Scannell and Cardiff attribute this to the non-commercial nature of the BBC: "If broadcasting in Britain emerged relatively unscathed from such withering criticism it was because the $\mathrm{BBC}$, like the cultural critics, rejected the profit motive as the basis of its institutional existence." 282 Finally something to agree on.

Ultimately, at the close of 1926, the British government accepted the recommendations of Reith and the Crawford Committee, and the British Broadcasting Corporation was born. Unlike the messy, chaotic situation in the United States, the British approach was more measured and restrictive of private enterprise. The fact that John Reith and the early British Broadcasting Company were so perfectly in tune with so many British cultural elites in and out of government was the main reason for their success. Most Britons, viewing the American approach to broadcasting as a cautionary tale, were pleased with the British use of the airwaves and were supportive of the institutionalization of the $\mathrm{BBC}$ as a public corporation operating what had been conceived of in Britain as a natural monopoly and a public service. While government control of such services was not unheard of in the U.S., it was far more likely to be accepted in

${ }^{282} I d$. at 17. 
Britain due to a history of public control of such aspects of industry, such as the telegraph. Thus, path-dependent processes continued to shape the role of the state in the market and society. Causal chains that had been broken in the 1920s were beginning to reform as the critical juncture was coming to a close. The main difference seems to be that the chains were broken much longer in the United States as debate ensued and interests collided throughout the 1920s. For Britain and the $\mathrm{BBC}$, the period of greatest contingency appeared to be at the start of the 1920s before the original Company was formed. The early decision to form a heavily regulated monopoly followed by the success of Reith did much to push aside open competition as a policy alternative. In the United States, it was just the opposite: public ownership and control was pushed aside as communication companies were given time to dominate broadcasting in fact if not yet in law.

\section{CONCLUSION}

This comparative analysis of path-dependent processes reveals that the eventual, divergent broadcasting policy outcomes in the United States and Great Britain, far from being inevitable, were contingent on different understandings of the public interest. In Britain, the public interest remained tied to earlier notions of public service, which suggested a regulatory approach that would treat broadcasting more like a public utility than a commodity to be bought and sold. In the United States, the public interest over time became wedded to notions of technological efficiency and economic consumption that gave preference to the 
dominant commercial broadcasters and their advertising-supported networks. Independently, these findings are not terribly surprising, given that they are consistent with previous research. But the comparative approach used here and the attention to path-dependent processes helps this article achieve its goal of highlighting and explaining the different causes and conditions that led to divergent outcomes.

Thus, this study has attempted to make three contributions to the existing literature. First, by employing a comparative approach, this work gains comparative leverage that helps to identify the differences in the regulatory approaches taken in the United States and Britain. Second, by taking a long view and focusing on institutional development and path-dependent processes, this work has identified the different trajectories and paths not taken that led to the divergent outcomes. Third, this work has attempted to shed light on the tensions that arise between markets and society with attention to the role of the state in regulating communications in particular and industry in general.

First, comparative historical analysis is useful for examining social phenomena that occur in limited numbers and on large scales over long time frames. The historical development of broadcasting is this type of social phenomenon, and the comparative approach helps accentuate the differences in outcomes and their causes. Histories that focus exclusively or primarily on the origins of broadcasting in a single country are limited to the debates and deliberations that took place in the country being investigated. This study gains 
comparative leverage by contrasting the private, commercial, advertisingsupported system of broadcasting that emerged in the United States with the noncommercial, public monopoly that dominated in Britain. The contrast emphasizes the point that the American outcome was far from inevitable and could have easily turned out different. This is also evident in the intense struggles to control and influence broadcasting policy between the Department of Commerce, the Navy, the Post Office, various members of Congress, the communications corporations that dominated private broadcasting, other private broadcasters such as universities, churches and political groups, and amateur operators and hobbyists. These American struggles contrast sharply with the comparatively stable regulatory approach in Britain beginning with the birth of the British Broadcasting Company in 1922.

Second, the historical comparison highlights the path-dependent processes that led to these divergent outcomes. The long tradition of government control of communications in Britain stands apart from the American tendency to promote private entrepreneurialism and technological innovation that led to the massive growth of radio in the United States. These different regulatory approaches were informed by increasingly different conceptions of the public interest in the two countries beginning in the nineteenth century. While it is important to "break the chain" of path dependence in order to avoid the problem of infinite regress, the development of electric communication, particularly the telegraph, in the 1800s represents an earlier critical juncture with clear path- 
dependent outcomes in both countries. The outcomes for broadcasting were never guaranteed, but forces of inertia helped to perpetuate policy scripts that would limit private business in Britain and support it in the United States.

Furthermore, the temporal sequencing of the development of broadcasting suggests that the United States, in that it was first in developing radio, served as a cautionary tale in Britain. This is interesting not just because the timing helped to dictate the outcome but also because the British reacted by deciding that the American chaos was unacceptable. The acceptability of the chaos in the United States and not in Britain speaks to the different views of the role of the state in society generally in allowing or restricting individual selfinterest. Failures to understand the technology aside, the individualistic nature of the race to develop radio despite the chaos it produced was an acceptable tradeoff in the United States, where regulatory intervention giving preference to industry was generally favored over the more citizen-oriented British approach. What if the causes of the different policy outcomes had been different? What if World War I had further delayed American commercial development of radio and Britain had gone first? Given the tradition of British government regulation of communications, it seems likely that Britain would have pursued a BBC-type outcome even without the cautionary tale from America. Now consider the American alternative. What if control of radio had been handed to the post office or the Navy, both entirely possible outcomes before and after the first world war? It is easy to imagine a scenario where this would have led to a 
system of government-controlled national radio, although this likely would have given way to a hybrid competition model much faster than it did in Britain.

Third, the different policy causes and outcomes can be better understood and explained through sociological analysis, using such concepts as Polanyi's double movement, which highlights the tendency to restrain growth in the face of social disruption. The different outcomes in communication policy speak to the stronger British tradition of restraining growth in the face of market expansion, especially compared to the United States, where growth and expansion have often been the central goal of policy. These differences can be thought of as an outgrowth of the Industrial Revolution, which began in Britain before it did in the United States. This speaks to fundamentally different approaches to the regulation of markets in order to ease the tensions created in society. The rise of markets and the capitalist ethic led to different attempts to balance individual interests with the interests of the community, and these understandings are reflected in the institutional structure of media.

At the same time, there are a number of noteworthy similarities in the outcomes in U.S. and British broadcasting, and they can be tied to similar causes. The similarities between the two countries were noted earlier, and it is these basic similarities that help make the comparison possible. It is worth noting that both countries were sufficiently equipped to develop radio broadcasting at about the same time. Both countries created new systems of mass communication that brought media content into people's homes, changing the way people received 
and related to news, information and entertainment. Both countries elected to issue licenses and create some sort of regulatory structure; neither seriously considered a free market for spectrum or a complete government takeover. And, over time, both countries have adopted a hybrid model of public and private broadcasting, although the public media tradition remains far stronger in Britain.

Finally, both of these systems, rather than being structured with a great deal of public input and consideration, were top-down systems, organized by powerful actors and imposed upon the masses by administrative bodies. Neither approach can hardly be considered democratic. This pattern is evident throughout the history of communication. In The Master Switch, Columbia University law professor Tim $\mathrm{Wu}$, who coined the phrase "network neutrality," describes what he calls "the Cycle," or the process that occurs as a new communication technology becomes dominated by powerful actors. Simply put, it goes from an open to a closed system:

History shows a typical progression of information technologies: from somebody's hobby to somebody's industry; from jury-rigged contraption to slick production marvel; from a freely accessible channel to one strictly controlled by a single corporation or cartel - from open to closed system. It is a progression so common as to seem inevitable, though it would hardly have seemed so at the dawn of any of the past century's 
transformative technologies, whether telephony, radio, television, or film. ${ }^{283}$

The development of broadcasting in both the United States and Britain seems to represent this process of the closing of a system, but the closed systems that resulted had very different aims.

"The brute force of monopoly" was the language used by John Reith of the $\mathrm{BBC}$ to describe the manner by which the British broadcasting system came to be; if there is to be competition, he said, it will be for "cheapness, not goodness." ${ }^{284}$ But Reith unapologetically resisted the democratization of broadcasting and fought charges of elitism and paternalism by saying he was justified in controlling the content of the media because he had benefited from the education and cultural enlightenment that he thought everyone should be able to access. The notion of "noblesse oblige" figures prominently in this approach, as well as Reith's determination not to turn a resource as valuable as the airwaves over to commercial interests but rather to preserve the airwaves as a system of continuing education. This represents a fundamentally positive conception of liberty, which is used to justify government intervention in the marketplace to serve the public interest.

\footnotetext{
283 TIM WU, THE MASTER SWITCH 6 (2010).

284 Report of the Broadcasting Committee 1949, supra note 45, at 364.
} 
In America, the structure and regulation of broadcasting was more heavily influenced by the rise of capitalism in the mid-1800s as it took hold of American life; structures and institutions quickly emerged that made commercialization the dominant approach to regulating society. Faith in the democratic ideal encouraged the freedom of markets and a theoretically negative conception of liberty that limited government's ability to interfere in business. To the contrary, however, government worked in many ways to structure society to serve markets and justified this as a different type of public interest.

The British approach was far closer to what one would expect from a reasonable normative understanding of the public interest, in the sense that it serves the larger public good of improving the conditions of democracy and freedom. As Mike Feintuck argued, the public interest from a normative perspective can "be endowed with strong democratic credentials," and "its adoption as an interpretive principle, emphasizing the value of equality of citizenship, within the legal and regulatory systems, is not only advisable, but necessary, in the protection of democratic values." 285 The evidence explored in this study suggests this type of normative definition was more fully embodied in the British approach to broadcasting.

With regard to similarities and differences between U.S. and British broadcasting, it is important not to overstate the impact of path-dependent

${ }^{285}$ FEINTUCK, supra note 71, at 255. 
processes and critical junctures in order to avoid an overly deterministic view. To the contrary, path dependence and critical junctures can be used to highlight the contingent nature of communication policy. The development of radio was at least part historical accident in that no one could have been sure what the technology would eventually become. It is for reasons like this that we must remember to look forward from the past rather than backward from the present when conducting historical analyses.

Future research should continue to explore institutional origins of communication policy and structures, and scholars should continue to apply an interdisciplinary approach, making use of such tools as path dependence, historical comparison and sociological analysis. As Pierson notes, theoretical work on sources of institutional origins and change in general "continue to be sketchy at best," 286 so this is certainly an area of communication studies ripe for further exploration. More specifically, future studies should pay careful attention to the path-dependent processes of the early- and mid-1920s, as well as the debates that took place during this period about the role of the state in regulating communications in the United States. In general, future studies should continue to explore the types of media structures and institutions best suited to enhance democratic practices. There is a real need for increased discussion and evidence related to whether and how media, properly insulated from government and

286 PIERSON, supra note 10 , at 103. 
commerce, can serve self-governing citizens better than market-based

alternatives. The lessons of the 1920s broadcast policy debates, especially when

viewed in a comparative context, still have much to teach us as we move forward in the digital age and attempt to find a balance between public benefit and private desire. 